\title{
Ecological Study of a Muskrat Population
}

\author{
Eric LE BOULENGE \& Paule Y. LE BOULENGE-NGUYEN
}

Le Boulengé E. \& Le Boulengé-Nguyen P. Y., 1981: Ecological study of a muskrat population. Acta theriol., 26, 4: 47-82 [With 8 Tables \& 12 Figs.].

The dynamics of a muskrat population was studied from February 1970 to January 1972 on a fairly isolated stretch $(7.5 \mathrm{~km}$. long) of the river la Houille in South-Belgium, by capture-mark-release followed by a complete extermination on all of the hydrographic basin of the river. Regular controls around the plot allowed the detection of dispersal movements. The "Calendar of Captures" density estimation method has been modified, subject to the possibility of distinguishing between native and immigrant newcomers. This smodified Calendar of Captures " method does not assume equi-trappability for all of the population members: it supposes an equal disappearance rate of marked and unmarked native animals, and a negligibly small probability of escaping capture all together for the rest of the population. The annual population dynamics shows the following pattern: (1) winter density is stable from year to year, around 3 individuals $/ \mathrm{km}$. (2) A decline of about $50 \%$ occurs in spring, by emigration (of the type »saturation dispersal") as well as by death. Several arguments based on spatial and social behaviour and on trappability, indicate this decline is a manifestation of a natality regulating mechanism. (3) Through reproduction, density reaches a peak of $11 / \mathrm{km}$. in July, the subsequent autumn decline towards winter level is due to mortality of young, acting differentially on the successive cohorts. The proximate causes of this differential action seem to be spatial competition and the adult female's aggressiveness, (4) Some reshuffling of the population's members occurs in fall. (5) Annual mortality is 80 to $90 \%$ in adults; mortality before the first winter is 80 to $90 \%$ in young ones.

[Labo. Ecol. théor. et Biom., U.C.L., place Croix du Sud, 5, B-1348 Louvain-la-Neuve, Belgium].

\section{INTRODUCTION}

To qualify and quantify regulation processes is one of the major goals of population dynamics (e.g. Krebs, 1972). Small mammals are a favorite materiai for such studies, but they entail methodological and conceptual difficulties (e.g. Smith et al., 1975; Hansson \& Andersson, 1975). These may be reduced by a judicious choice of study species and site. This paper presents a study of year-round population dynamics of muskrats on a quite isolated river stretch, and examines some potential regulating mechanisms.

The choice of the muskrat as a study species is based on the following: 1) after its introduction into Europe as a fur-bearer, the muskrat colonized most of the continent, starting with escapes from breeding farms. 
This resulted in frequent dam-breaks, and actually most European countries are engaged in extermination campaigns, generally with moderate success (complete extermination only in Great-Britain, Warwick, 1940). Whence this species is of considerable economic importance in these countries (e.g., Moens, 1978 for an account of the state of affairs in Belgium). 2) Some ecological characteristics of the muskrat in Europe (reviewed in Le Boulengé, 1972) make it a very suitable study species. But whereas a large volume of published data give a good picture of its ecology in still waters, especially in its native Northern America (Errington, 1963), few studies relate to river-inhabiting populations. The following elements seem well established and concern directly population regulation processes: (a) the muskrat tolerates very ample climatic diversity and fluctuations, excepting floods after the onset of reproduction and prolonged drought or complete freezing of ponds. Such extreme conditions occur regularly in the more continental Northern America, but are exceptional in Belgium. Fluctuating water levels are unfavourable, as they prevent the establishment of stable burrows or lodges (Bellrose \& Brown, 1941; Bellrose \& Low, 1943). (b) As concerns its diet, this rodent is a broad generalist, consuming most aquatic plant species, and eventually shifting to terrestrial plants or even to carnivorous diet if needed (Chu Ching \& Yien Chih Tang, 1965; Errington, 1943); the distribution of consumed plant species seems to reflect their distribution within the habitat (Errington, 1939 b; Lavrov, 1957; Arata, 1959). (c) Predation is mainly due to the mink in Northern America, and from our observations (see later), could be taken over by the polecat in Belgium. Its impact at the population level could be low, being related to the level of mortality from other causes (Errington, 1943). (d) We found of no study on interspecific competition involving the muskrat; it seems that in Europe, no species overlapping its niche could successfully compete with it (see Chappellier, 1933).

The choice of a river as a study site is based on its unidimensionality, relative isolation, and the easiness of estimating population parameters and controlling dispersal on such a habitat.

\section{STUDY SITE, MATERIAL AND METHODS}

\subsection{Study Site}

The general study site comprises almost all of the hydrographic basin of the river la Houille in South-Belgium, (Fig. 1) covering approximately $150 \mathrm{~km}^{2}$. It will be called hereafter »extenstve site", to distinguish it from an »intensive site within it; these two parts deserved distinct and complementary purposes. The river and its associated creeks are very typical of the South Belgian highlands, and are well separated from other river basins by the Ardennes high 
plateau. The soil is calcareous and schisteous; surrounding vegetation comprises mainly deciduous forest, pine plantations and abandoned pastures. Aquatic vegetation is only abundant in the upper third of the river, with mainly Iris pseudacorus L. and Juncus effusus L. The river collects waters from about 350 ponds ranging from about 0.01 to 9 hectares; most are artificial and used for fishing.

The extensive site served for various field observations, for controlling muskrat movements from- and towards the intensive site and for collecting specimens. Kill trapping was performed on the third (107 ponds) of the extensive site in June-July and September-November 1970, and a complete extermination trial was conducted from October 1971 to February 1972, with the assistance of the

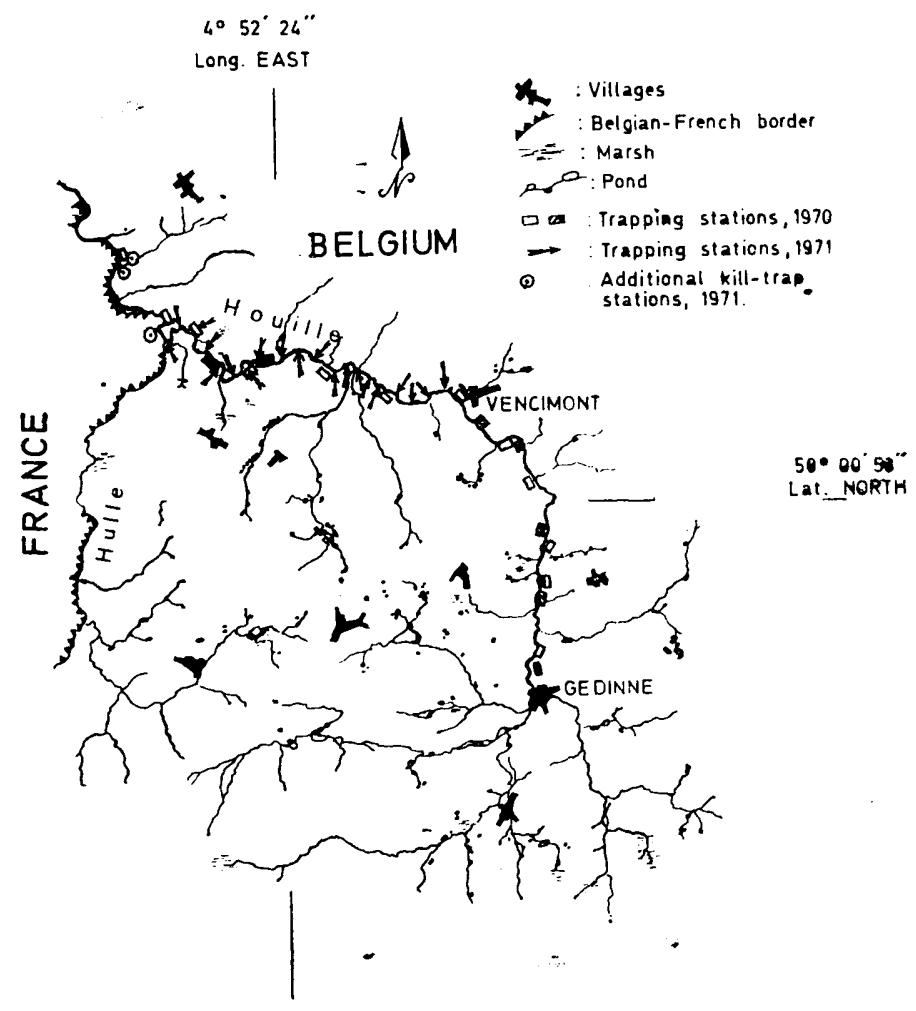

Fig. 1. Hydrographic basin of the river "La Houille», South-Belgium.

governmental muskrat extermination Service. The intensive site was a stratch of variable length located on the second third of the river, where the valley is cieep and few creeks join the river. It was used to follow the year-round muskrat population dynamics, according to the trapping design explained below.

\subsection{Trapping Design and Methods}

The catch-mark-release (C.M.R.) method was used to follow year-round population dynamics of muskrats on the intensive site. We used the single-catch live- 
and kill-traps shown in Fig. 2, baited with apple. Live-traps were checked 24 hours after being set. The captured muskrats were ear-tagged with numbered "Michel" chirurgical clips, which from our experience are safer than classical small mammal tags, and are niot likely to affect survival as is toe-clipping (see Akkermann, 1973, for a review of tagging techniques for muskrat). The schedule of trappings performed in 1970 and 1971 on the intensive plot is given in Table 1. In / 1970 it consisted of 2 distinct trapping periods, spring and autumn, on a $15 \mathrm{~km}$. river stretch (Fig. 1). "Trapping series " (consecutive trapping days) varied in length, and traps were frequently moved in spring.

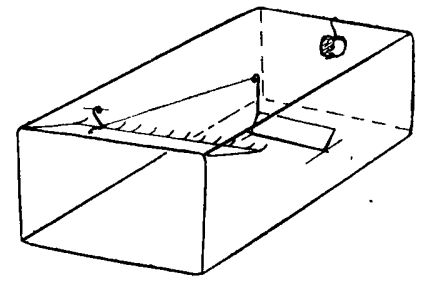

A

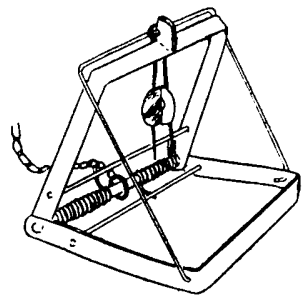

B

Fig. 2. (a) Life-trap (original type), (b) Kill-trap ("Kauderfalle").

In 1971, trapping began with a "scanning " of a $7.5 \mathrm{~km}$. plot, the lower half of the 1970 plot; a $1 \mathrm{~km}$. line of traps at $30 \mathrm{~m}$. spacing, was set and checked for 3 consecutive days and then moved on the next $1 \mathrm{~km}$. stretch. Thich scanning was followed by the regular 1971 schedule, consisting of a 3-day trapping series every other week, except for a gap in May and October-November. The last

Table 1

Trapping desing of C.M.R. experiments in 1970-1972.

\begin{tabular}{|c|c|c|c|c|}
\hline & $\begin{array}{c}28 / 02 / 70- \\
7 / 05 / 70\end{array}$ & $\begin{array}{c}16 / 09 / 70- \\
13 / 11 / 70\end{array}$ & $\begin{array}{c}25 / 01 / 71 \\
19 / 03 / 71\end{array}$ & $\begin{array}{c}27 / 02 / 71- \\
15 / 02 / 72\end{array}$ \\
\hline $\begin{array}{l}\text { No. trap. days } \\
\text { No trap groups }\end{array}$ & 48 & 28 & 24 & 64 \\
\hline (no./group) & $10(5)$ & $10(5)$ & $1(30)$ & $20(4)$ \\
\hline No. trapnights & 1.240 & 771 & 720 & 3.901 \\
\hline Intergroup distance (m.) & 1.500 & 1.500 & - & 390 \\
\hline Lenght of plot (km.) & 15 & 15 & 7.5 & 7.5 \\
\hline Remarks & $\begin{array}{l}\text { Variable } \\
\text { location } \\
\text { of trap } \\
\text { groups }\end{array}$ & $\begin{array}{l}\text { Fixed trap } \\
\text { location: } \\
\text { odd \& even } \\
\text { groups alter- } \\
\text { natively set } \\
\text { checked }\end{array}$ & $\begin{array}{l}\text { »Scanning«: } \\
\text { one moving } \\
\text { trap-line } \\
\text { (see text) }\end{array}$ & $\begin{array}{c}\text { 3-day trap- } \\
\text { ping series } \\
\text { every other } \\
\text { week }\end{array}$ \\
\hline
\end{tabular}

trapping series, in January 1972, was a kill-trapping with »Kauderfalle traps (Fig. 2 b) replacing the life traps, and was the end-point of the extermination campaing on the extensive site. These kill-traps were left and regularly checked till mid-February 1972. 


\section{RESULTS}

Our basic data consist of the muskrat captures realized during 295 days on the field between March 1970 and January 1972. As a total, 843 captures of 281 muskrats were obtained on the intensive plot, while 578 individuals were trapped on the extensive plot, mainly in ponds. We will be mainly concerned here with the dynamics of the muskrat

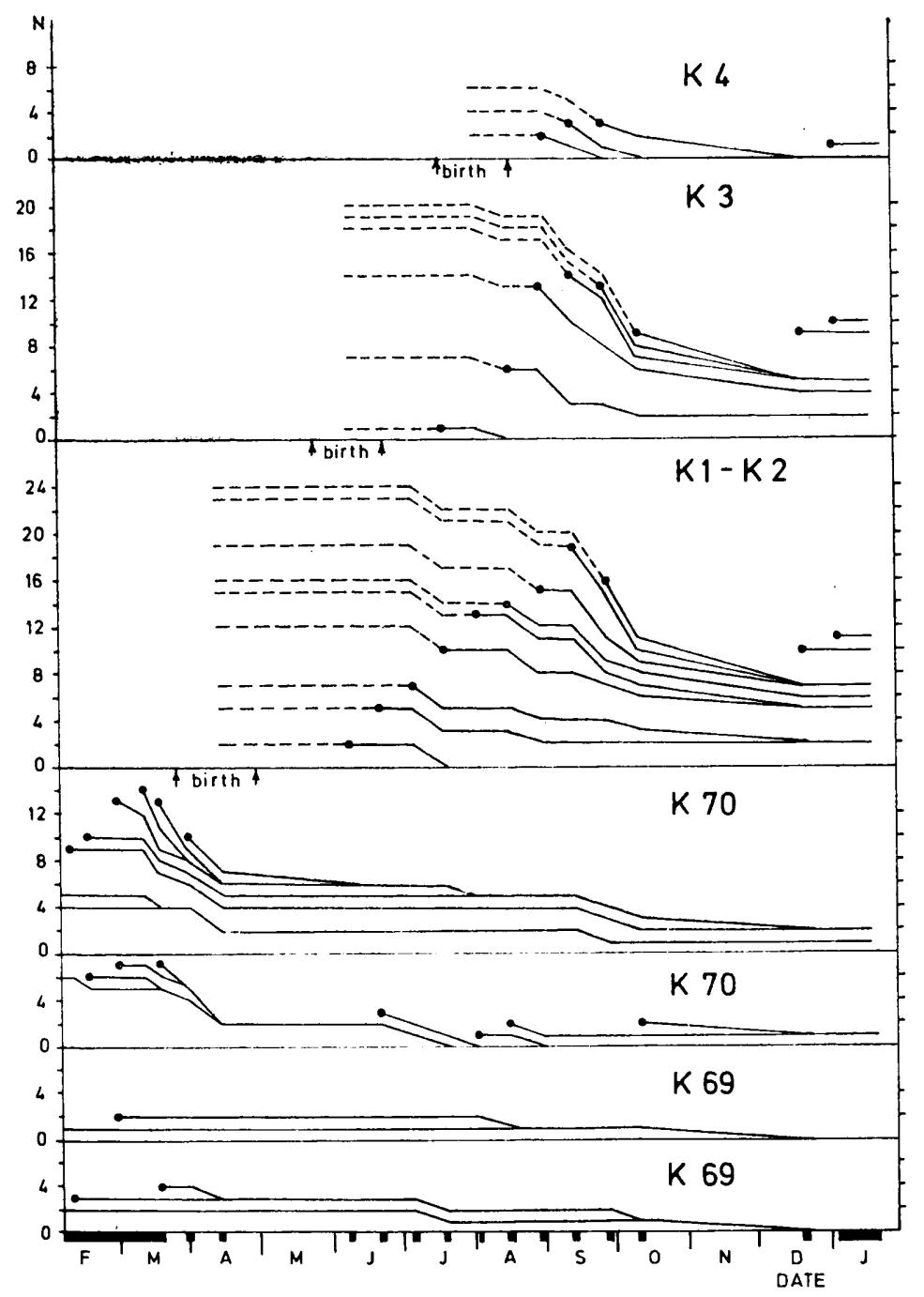

Fig. 3. Minimum number known to be present, taking account of the estimated residency time $\left(m^{\prime}{ }_{j k}\right.$ in Appendix I). These numbers are splitted according to the date of appearance on the plot. $K-69 \ldots K-4$ : cohorts. Black spots along the base line: trapping series. 
population on the intensive plot in 1971; data from 1970 are more dubious owing to inadequate trapping design, and will be used for some comparisons. The 1971 data are illustrated in Fig. 3, showing for each age cohort, survival of the individuals on the plot (see Appendix I for more details about the construction of this figure).

\subsection{Dynamics of Numbers}

Due to small sample sizes and inadequacy of classical statistical density estimation methods (see discussion), density during 1971 on the intensive plot was basically derived from the "Calendar of Captures " method (Andrzejewski, 1969). Certain characteristics of our data allowed us to improve the method by taking into account an estimation of the

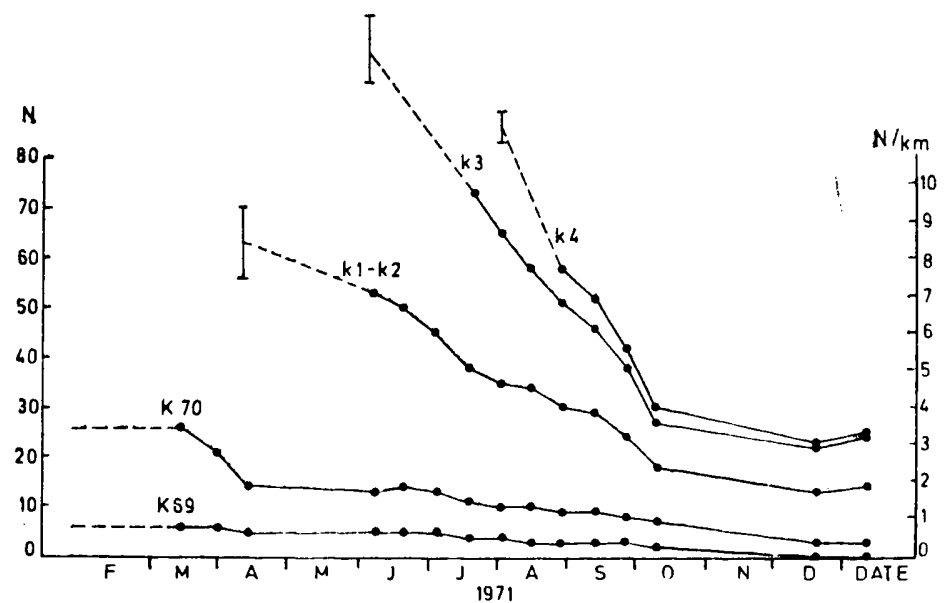

Fig. 4. Population dynamics of muskrats on the intensive study plot during 1971 (modified C.C. method), per cohort.

Left-hand scale: density on the entire plot. (N: no. of individuals). Right-hand scale: density per $\mathrm{km}$. of river. $(\mathrm{N} / \mathrm{km}$.).

K-69 ... K-4: cohorts. Vertical bars minimum to maximum estimated natality at the cohort's man birthdate. Dotted lines: for $K-69-K-70$ : single estimate for the "scanning " experiment in February-March, for $K-1$... K-4: hypothetical density curve from birth to the date of the first density estimation, Sf (see Appendix I).

"real « residency time of the individuals on the plot, and the mortality of native young before first capture. The details of this "modified Calendar of Captures " method are explained in Appendix I. Density was estimated by this method separately for each cohort, in order to prevent any bias due to a possible age-dependence in the disappearance rates. See $\S 3.2 .1$. for the construction of cohorts, and $\S 3.3 .3$. for the recognition of immigrants. Resulting population dynamics is presented in 
Fig. 4. The January 1972 figure was estimated by the regression method of Hayne (1949 a), as $28 \pm 1$ individuals (95\% c.i.).

During 1970, density on the intensive plot could not be estimated by the modified C.C. method, as the needed information was not available. We used instead the Manly \& Parr (1968) method; for the sake of comparison, the latter method was also applied to the 1971 data. Fig. 5 illustrates, for both years, the minimum number known to be present (Calendar of Captures), the estimates given by the Manly-Parr method,
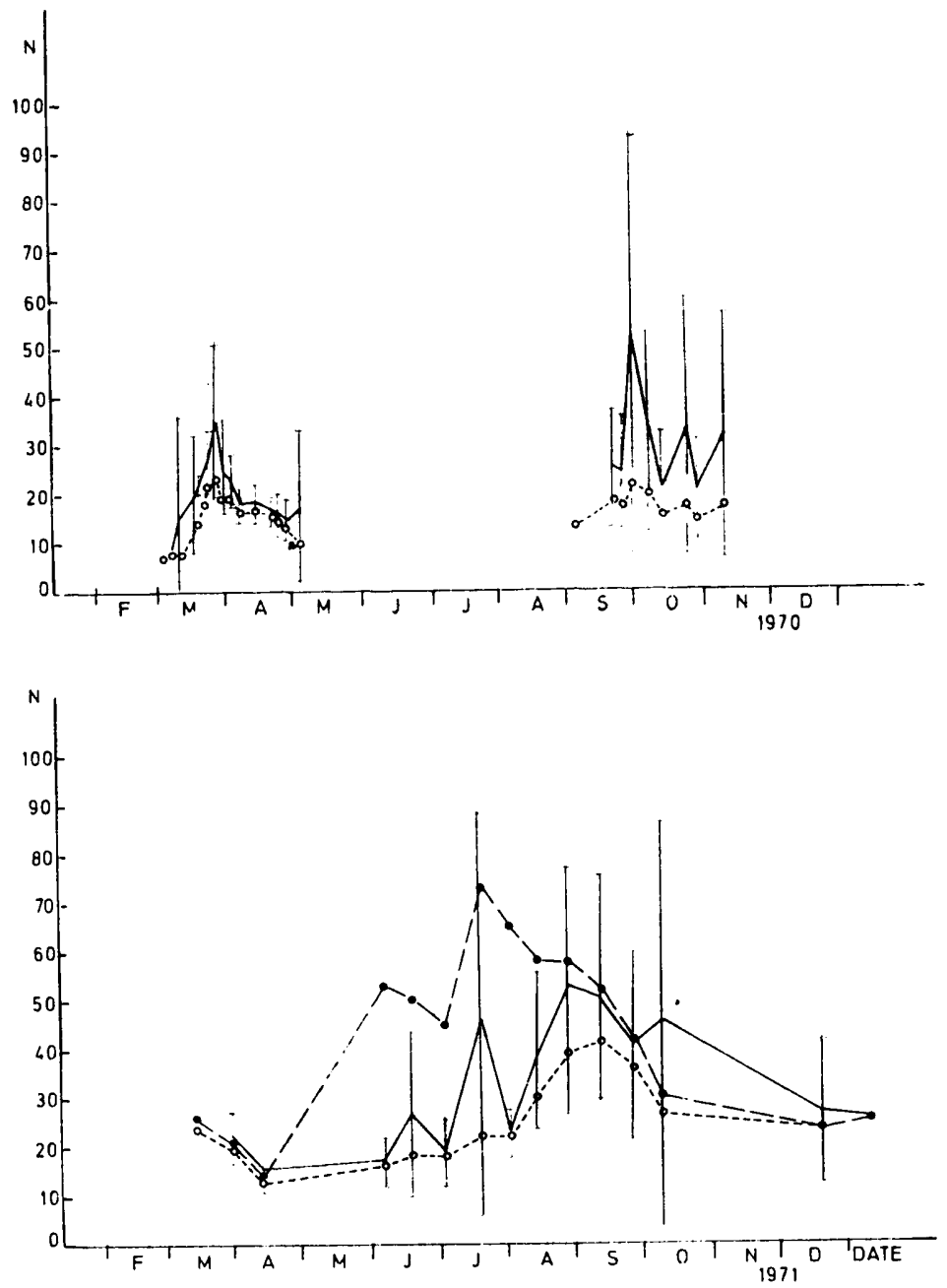

Fig. 5. Density estimations on the 1970 and 1971 intensive plots by the Manly \& Parr (1968) method.

Continuous lines: Manly and Parr estimates (vertical bars: $95 \%$ c.i.). Interrupted line: estimates by the modified C.C. method (1971). Dotted lines: minimum numbers known to be present. 
and for 1971, those by the modified Calendar of Captures. The Jolly (1965) method was also applied to this data set with results very similar to those of the Manly-Parr method. It may be seen that all methods converge in winter-spring, a period of high trappability, but diverge thereafter. See discussion for further comments.

Some interesting results may be noted: (a) Winter population density was very similar in 1970,71 and $72: 36$ muskrats were captured on the $7.5 \mathrm{kms}$. corresponding to the 1971 plot in February-March 1970, versus 33 in February-March 1971. On the other hand, the density estimation of 26 individuals in March 1971 is close to that of January 1972 (28 individuals). (b) A decrease of about $50 \%$ occured between mid-March and mid-April 1971; a similar decrease was noted in the spring of 1970 . (c) Starting with 14 survivors in April 1971, the population reached a summer peak of about 100 individuals, next decreasing progressively towards its winter level of about 30. (d) The right-hand scale of Fig. 4 represents density per $\mathrm{km}$. of river. As no border effect was detected by the method of Pelikan (1969) (comparing numbers of captures in inner and outer trap-groups on the assumption of homogeneous probability of capture across trap groups), the effective plot length was taken as the trapped plot, plus one half of the distance of $300 \mathrm{~m}$. between last trap of a group and first trap of the next; this yielded an effective plot length of $7.8 \mathrm{~km}$. The mean river breadth being of $5 \mathrm{~m}$., we may tentatively equate one $\mathrm{km}$. of river to one hectare, considering that muskrats do not dwell farther than $2-3 \mathrm{~m}$. from the river banks, as is suggested from our observations of foot-prints in mud and snow. Thus the right-hand scale of Fig. 4 may be considered to give an order-ofmagnitude indication of density per hectare.

\subsection{Population Structure}

\subsubsection{Determination of Sex- and Age-ratio}

Sex ratios were estimated from the samples caught at each trapping series. We determined the sex of live muskrats by observation of external genitalia (Baumgartner \& Bellrose, 1943). The validity of our sexing technique was controlled on a sample of 500 muskrats by dissection, yielding $1.5 \%$ misidentification.

For determining the age of live-trapped muskrats during 1971, we used the following strategem first we assembled the young of the year into »probable litters « (a term coined by Neal, 1968), next we grouped these litters into cohorts according to their growth characteristics, finally we estimated the birthdate of the cohorts, using those individuals or litters to which an age-estimation method could be applied (extrapolation 
pi tail growth, or lens weight: see Le Boulengé, 1977). Only step 2 could be applied to adults, as few of them were kill-trapped and could be aged by lens- weight. Grouping of young into "probable litters " was based on the following arguments: (a) young individuals stay on their mother's reproduction territory till an age of approximately 3 months. (b) Reproduction territories on our field were well segregated throughout summer (Fig. 8), whence each captured young could be assigned to one territory. (c) The age difference between a female's successive litters is over a month (Dorney \& Rush, 1953; Olsen, 1959; Moens, 1961; Vincent \& Quéré, 1972). The growth curves of the litters are thus well separated on the time axis (Fig. 6).

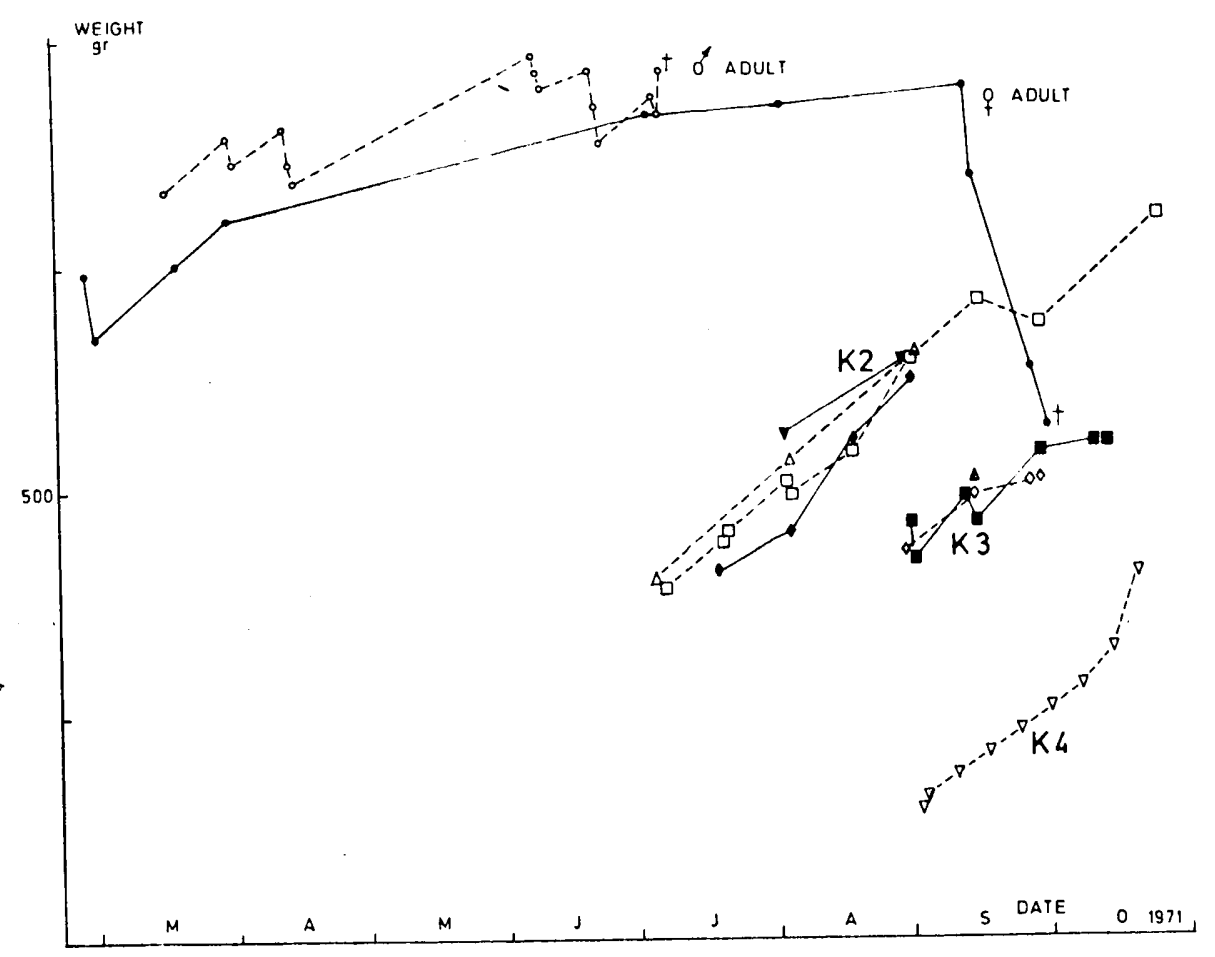

Fig. 6. Weight fluctuations of all individuals caught on one reproduction territory on the intensive plot in 1971.

By graphical comparison of their growth curves, the litters were grouped into 4 cohorts of young born during 1971: cohorts $K-1$ and $K-2$, born in March and April, group the first litters respectively of precocious and tardive females; cohorts $K-3$, born in June, and $K-4$, born at the end of July, are the second and third litter. 
Among the adults present on the study plot during 1971, we could distinguish 2 "cohorts", according to their prior capture history or to their weight fluctuations in winter 1970-1971 for those not caught before this: $K-70$, first year adults, consisted of those captured as young in the autumn 1970, or weighing less than $1000 \mathrm{gr}$. in winter; K-69, older adults, grouped those marked since spring 1970, or captured as adults in autumn 1970 , or weighing more than $1000 \mathrm{gr}$. in winter. No individual known to be born in 1970 reached $1000 \mathrm{gr}$. in the $1970-1971$ winter, and no one known as adult in 1970, fell below $1000 \mathrm{gr}$. in that season.

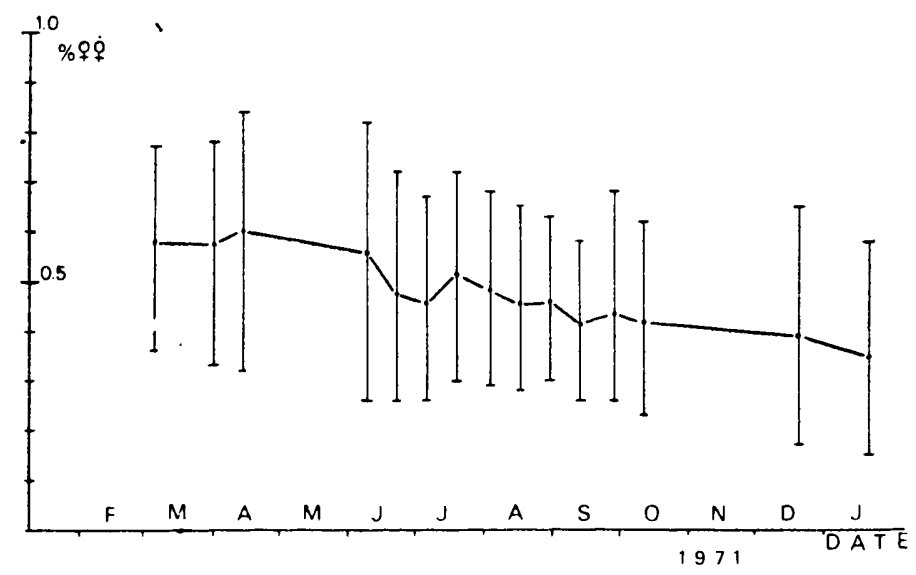

Fig. 7. Sex-ratio on the intensive plot during 1971.

Proportions are derived from the total number of individuals effectively caught at each trapping period. Vertical bars: $95 \%$ confidence interval for the proportions.

\subsubsection{Sex and Age Structures}

Fig. 7 represents the fluctuations of sex-ratio during 1971 , as determired from the sample caught in each trapping series. Although no single value differed significantly from a $1: 1$ ratio, the observed proportion of females progressively declined from spring to autumn. Males never outnumbered the females among adults, and the reverse in young. These results are in accordance with most published evidence (see Le Boulerigé, 1972). Age ratios may be reconstructed from Fig. 4. The most outstanding feature is the sharp decline of the proportion of first-year adults in spring. We observed an equivalent proportion of adults in two successive autumns $(34 \%$ in $1970,27 \%$ in 1971) and winters (19\% in March 1971 , $13 \%$ in January 1972$)$. 


\subsection{Demographic Processes}

\subsubsection{Natality}

Natality on the intensive plot during 1971 was determined in 3 steps. (a) number of reproducing females: the number of adult females present on the plot during the 1971 reproduction season, was known with high confidence owing to their high trappability in winter and spring ( $\S 3.4 .4$.) and their sedentarity thereafter ( $\S 4.2$.). Thus 7 females held territories from March-April to August 1971 and had young animals captured on their territories. No female immigration was observed after April. (b) Number of litters per female: by the same argument as in $\S 3.2 .1$. we could determine the number of litters each female had during 1971 (i.e. Fig. 6), assuming at least 1 young of each litter would be captured. We thus observed 7 litters of $K-1$ and $K-2$ (26 individuals captured), 7 litters of $K-3$ (27 individuals captured) and 4 litters of $K-4$ cohort ( 7 captures), with an average of 2.3 litters per female. This result is in agreement with bibliographic data for the muskrat in Europe (Moens, 1961; Vincent \& Quéré, 1972).

(c) Number of young per litter: in order to determine the number of young per litter, we tried to use placental scars counts on females captured during the winter 1971-1972 kill-trapping; this technique proved unreliable due to the preservation technique, but at least it confirmed that no young-of-the year female reproduced that year. Relying on bibliographic data, we assumed a mean litter size of 6 fo 8 young (Chappellier, 1933; Errington, 1937; Beshears \& Haugen, 1953; Dorney \& Rush, 1953; Sather, 1958; Olsen, 1959; Erickson, 1963; Mathiak, 1966; Vincent \& Quéré, 1972; Akkermann, 1975).

Resulting natality estimations are reproduced in Fig. 4: natality amounted to 42 to 56 young in $K-1$ and $K-2$ cohorts, 42 to 56 young in $K-3$ and 18 to 24 young in K-4 cohort, using respectively 6 and 8 per litter. Total natality amounted to $100-144$ young on the intensive plot in 1971.

\subsubsection{Mortality}

Only disappearance rate could be determined from capture-recapture data. Insofar as emigrated individuals are lost to the population, both may be pooled into an »ecological mortality rate« (Petrusewicz \& Macfadyen, 1970). The fate of individuals disappearing from the intensive plot could be ascertained by trapping on the extensive plot, and will be discussed later. Daily disappearance rates between trapping series were estimated from the data in Fig. 3, on the assumption that disappearance rate is constant between two successive series (Chitty \& Phipps, 
1966; see Appendix I); this assumption is not critical for short time intervals between series, as in the present study. The results are presented in Table 2. Disappearance rate is the lowest in the $K-69$ cohort throughout the year; that of $K-70$ cohort is high in spring, and similar to that of old adults thereafter. Among the cohorts of young of the yea:, disappearance rate is highest in the youngest cohorts: the proportions of marked animals surviving till the winter, are $4 / 8$ for $K-1,3 / 16$ for $K-2,5 / 20$ for $K-3$ and $0 / 7$ for $K-4$ young. Synthetically, if we assume all individuals disappearing from the plot died before the January killtrapping, the annual mortality of adults would be of $94 \%$ and that of young, of 89 to $92 \%$ (using respectively the minimal and maximal natality estimates). On the other hand, we might assume that all 17 individuals recaptured as emigrants of the extensive plot, would have survived till January if not kill-trapped; this would yield a 79\% annual mortality among adults, and 80 to $86 \%$ among young ones. Consequently, annual mortality of adults lays somewhere between 80 and $94 \%$, and mortality of young before their first winter, between 80 and $92 \%$.

Table 2

Mean daily mortality rate $(\boldsymbol{\mu})$, calculated on the assumption of constant rate between two successive trapping series (see text), and monthly survival rate $(\boldsymbol{\Phi})$, in percent, per period cohort. These values do not distinguish between emigration and death.

\begin{tabular}{|c|c|c|c|c|c|c|c|c|}
\hline \multirow{3}{*}{ Period } & \multicolumn{8}{|c|}{ Cohort } \\
\hline & \multicolumn{2}{|c|}{$K-69$} & \multicolumn{2}{|c|}{$K-70$} & \multicolumn{2}{|c|}{$K-1 \& K-2$} & \multicolumn{2}{|c|}{$K-3$} \\
\hline & $\mu$ & $\Phi$ & $\mu$ & $\Phi$ & $\mu$ & $\Phi$ & $\mu$ & $\Phi$ \\
\hline Jan.-June & -.0023 & 93 & -.0154 & 63 & & & & \\
\hline June-Oct. & -.0051 & 86 & -.0070 & 81 & -.0088 & 77 & -.0129 & 68 \\
\hline Oct.-Jan. & - & 0 & -.0056 & 85 & -.0049 & 86 & -.0092 & 83 \\
\hline
\end{tabular}

\subsubsection{Dispersal}

Dispersal movements in relation to the intensive plot in 1971 , could be detected or deduced on the following basis: (a) emigrations were controlled by regular trapping around the intensive plot throughout the year; owing to the efficiency of the final extermination compaign, it is likely that all emigrants still alive in January 1972, were recaptured by then; (b) immigrations were deduced from the timing of first captures: in adults, as the probability of escaping capture during the "scanning" experiment ( $\S 2.2$.) amounted to 0.03 , all individuals first captured after this were considerd as immigrants; in young-of-the-year cohorts, the distributions of first captures (Fig. 12) were clearly bimodal, with a group of several trapping occasions between the two groups; the individuals from the later groups, aged more than three months at first capture, 
were considered as immigrants; these immigrations were posterior to the first emigrants from the intensive plot; (c) excursions and home range shifts, finally, could in some cases be deduced from an analysis of the home range ( $\S 3.4 .2$.). Recognition of these dispersal movements was considerably facilitated by the unidimensionality of the study plot, high frequency of trapping, and high trappability of the animals.

The results are as follows: (a) between autumn 1970 and February 1971, 5 immigrations could be detected (animals outside the 1971 intensive plot in autumn, and inside when recaptured during the »scanning «; no emigration was detected during this period, perhaps due to lack of regular trapping outside the intensive plot. For this reason also, we have no data to quantify dispersal during 1970. (b) In spring 1971, no immigration was observed, while 7 of the individuals disappearing in this season were later recaught as emigrants. (c) In summer, besides 2 adults crossing the plot, only minor home range shifts were observed. (d) In autumn (September-December), timing of first captures revealed 10 immigrations, while 12 individuals were recaptured as emigrants. Distances moved by those animals caught before and after the movement, ranged between 1.5 and $8.5 \mathrm{~km}$. in spring (median $4.5 \mathrm{~km}$.) and between a hundred meters and $7 \mathrm{~km}$. in fall (median $1 \mathrm{~km}$., excluding a group of musk-rats emigrated to a pond some $50 \mathrm{~m}$. aside from the river). These revealed distances are likely to underestimate true dispersal movements and are to be taken only as indicative. Outstanding events are the emigration of at least $21 \%$ of the population in spring with no contemporaneous immigration, lack of dispersal movements in summer, and emigration of at least $17 \%$ of the population in fall accompanied by a numerically equivalent immigration.

\subsection{Ecological and Behavioural Attributes of the Cohorts}

Information was gained concerning growth, spatial and social behaviour, and trappability, from the C.M.R. data and from direct observation in nature and in captivity.

\subsubsection{Body Growth}

Results on body growth will not be detailed here, to avoid redundancy with the abundant data published on the subject (Le Boulengé, 1972). Growth curves obtained from our C.M.R. experiments and in captivity are very similar to those presented by Vincent \& Quéré (1972) and Akkerman (1975), growth rate was similar for spring-born $(K-1$ and $K-2$ ) and summer-born ( $K-3)$ young, with a weight of $300 \mathrm{gr}$. at the age of 50 days, and of 800 to $850 \mathrm{gr}$. at 200 days. The latter weight, 
reached in the fall, is maintained during the first winter and spring, later increasing to over $1000 \mathrm{gr}$. at the end of the second summer. The heaviest individual captured in this study weighed $1400 \mathrm{gr}$..

Qualitative data on the development of young muskrats in captivity, agree with the description given by Errington (1939 a), except for the age at which young muskrats start swimming: 2 weeks in Errington's publication, as compared to 1 month, with short periods of diving since the age of 3 weeks, in our study. As a rule. development and growth rates appear to be quicker in Northern America (Errington, 1939 a; Applegate \& Predmore, 1947; Dorney \& Rush, 1953; Erickson, 1963) than in Europe (Vincent \& Quéré, 1972; Akkermann, 1975; present study).

\subsubsection{Home Range}

Home range length estimation was based on the method of Mazurkiewicz (1969). Taking into account unidimensionality of the habitat, home range was defined as that length (instead of area) containing $95 \%$ of the individual's probability of presence, and was estimated as the $95 \%$ confidence interval for the capture loci. Individual home range length was estimated for those animals captured at least 3 times, and an average home range length was calculated per cohort and season, using the pooled capture data (expressed as deviations from the individual's Geometric Center of Activity, Hayne, 1949b) of the cohort's members captured at least twice in the concerned season. This way of pooling has been used by Dice \& Clark (1953), Mohr (1965) and Tanaka (1972). An empirical rule was constructed to defect excursions or home range shifts: using the animals caught at least 3 times, we first determined their modal capture location; next, we iteratively calculated the variance of their capture loci, including captures successively more and more distant from the mode. With more remote captures being included, the variance first increased smoothly, then stabilized, and finally eventually made a sudden "jump", when a very distant capture or group of captures was included. These were considered as outside the home range of the individual. As a cutting point between captures inside and outside the home range, we choose a distance from the mode, where all individuals studied beared a stabilized variance, and none had yet shown a jump in the variance of its capture loci. These conditions were met for a distance of $780 \mathrm{~m}$. from the mode; whence for home range estimations, all captures farther than $780 \mathrm{~m}$. from the individual's modal capture location, were excluded as being outside the home range.

The Normality assumption underlying the method of Mazurkie- 
Table 3

Pooled home range estimates in 1971, in different seasons. First figure is home range length (m.); number of captures is indicated in parentheses; $3 \mathrm{rd}$ and 4 th figures give the $95 \%$ c.i. In adults, summer and fall data had to be pooled, yielding a simple estimation for both seasons.

\begin{tabular}{lccc}
\hline Class of animals & Winter-spring & Summer & Autumn \\
\hline Adult males & $825(75)$ & \multicolumn{3}{c}{$792(22)$} \\
Adult females & $724-1002$ & $610-1130$ \\
& $939(62)$ & & $837(29)$ \\
Young $K-1$ & $813-1166$ & $472(19)$ & $666-1130$ \\
Young $K-2$ & & $357-698$ & $1757(16)$ \\
& & $790(22)$ & $1299-2717$ \\
Young $K-3$ & $604-1140$ & $2882(6)$ \\
& & $63(6)$ & $1798-7073$ \\
& & $39-155$ & $615(35)$ \\
\hline
\end{tabular}

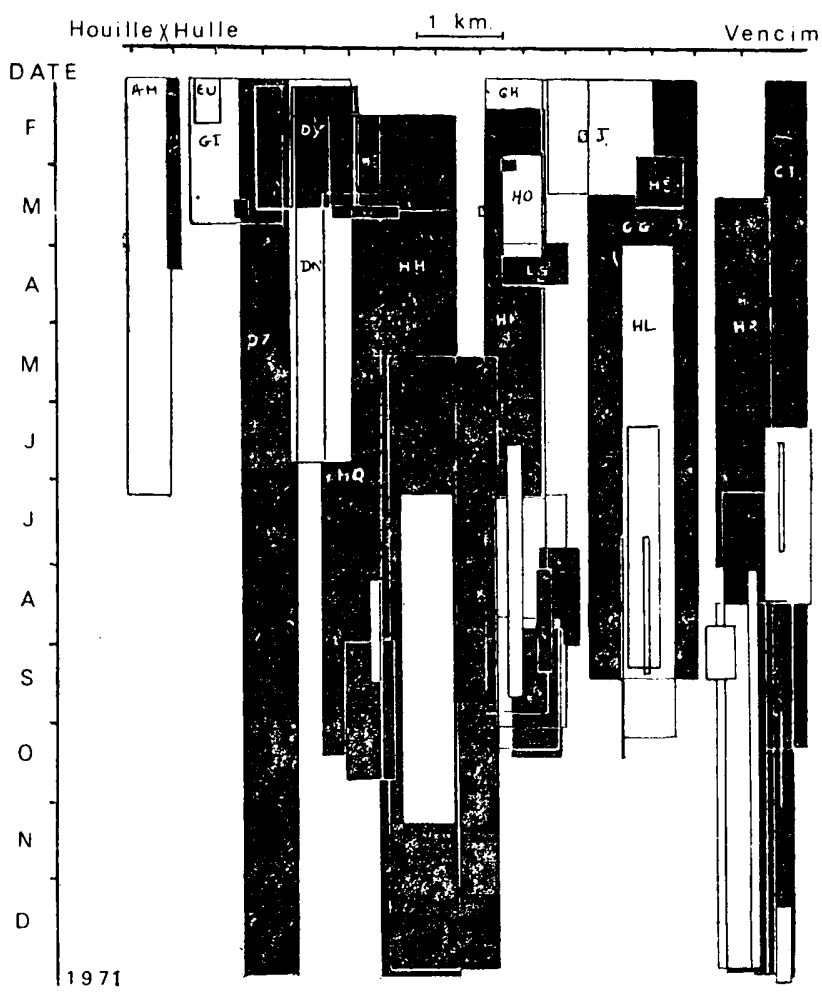

Fig. 8. Repartition of muskrats over time and space; intensive plot, 1971.

Each indvidual is represented by a rectangle of width proportional to the home range length, and neight proportional to the estimated residency time. Males: white rectangles, females: black rectangles; adults: tag symbols reported in the corresponding rectangle.

Only those individuals whose individual home range could be estimated (46) are reported; animals shifting home range are given 2 or more rectangles. 
wicz (loc. cit.) does not seem to be critical: although in the present study the observed distributions of capture loci around the Geometric Center of activity were more leptokurtic than expected according to a Normal distribution, home range length estimations as defined above closely corresponded to the smallest distance encompassing $95 \%$ of the capture loci (as obtained by plotting the observed repartitions of capture loci on probit paper). Pooled home range estimations per cohort and season are given in Table 3. Adult home range length is stable throughout the year, while that of young, small in summer, increases beyond the parental home range in fall, except for K-3 young.

Contrarily to these results, Sather (1958) and Neal (1968) reported the home ranges of young to be at least as extended as those of adults. As cbserved in the present study, Neal (loc. cit.) reported that young individuals increase their home range size after the age of 20 weeks (i.e. in fall). For 46 individuals captured at least 3 times during 19r1, individual home range and residency time is illustrated in Fig. 8. It appears from this figure that coverage of the plot and overlap of home ranges was more pronounced in winter and spring, than in summer and fall. Especially adult females had more disjoint home ranges in summer than in winter-spring.

\subsubsection{Social Behaviour and Territoriality}

Direct observations in captivity and on the field gave us some insights on social behaviour and territoriality of muskrats. Adult males were generally tolerant toward all classes of the population, excepting one period of increased aggressiveness in March, just before the onset of reproduction. In this period, we observed on the field two cases of chases between adult males. Adult females in captivity were hightly intolerant towards any foreign animal in the reproduction period (April-September), becoming more "social" in winter.

Young muskrats in captivity did not shown any sign of aggressive display until maturity. They were strongly rejected and eventually killed by adult females other than their mother, but on the contrary, they were easily accepted by foreign adult males; young individuals brought into captivity before the age of one month usually died except when put together with an adult male. Males appear to participate in the »education" of young, in relation with feeding and toiletting, and are not selective as to the origin of these young; adult females on the contrary are selective in favour of their own young.

\subsubsection{Trappability}

Trappability may be viewed in two ways: either as the probability of capture of one individual (individual trappability), estimated as the 
proportion of trapping days on which the individual was caught, or as the probability of capture of any population's member at a particular day (population trappability), estimated as the proportion of the individuals present which were caught on that day (i.e., the trappability estimator of Manly \& Parr, 1968) see Appendix I. Population trappability per 3 days trapping series is illustrated in Fig. 9, showing a higher

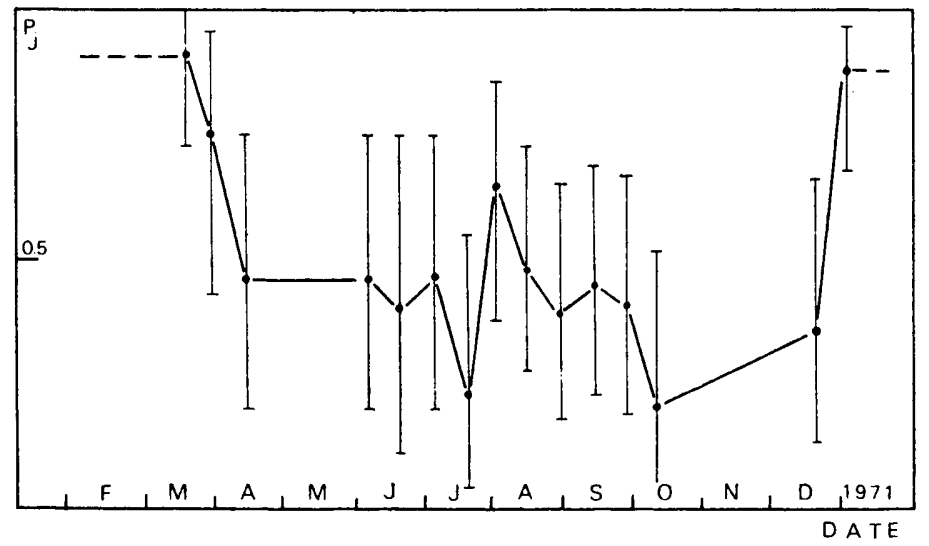

Fig. 9. Population trappability per series in 1971. Vertical bars: $95 \%$ c.1.

Table 4

Test of goodness of fit between distributions of number of trappings between successive captures, and Geometric distributions.

\begin{tabular}{|c|c|c|c|c|c|}
\hline $\begin{array}{c}\text { Cohort and } \\
\text { season }\end{array}$ & $\begin{array}{c}\text { Mean number } \\
\text { of trappings } \\
\text { between } \\
\text { capt. }\end{array}$ & $\begin{array}{l}\text { Individual } \\
\text { trappability }\end{array}$ & $\begin{array}{l}\text { Observed } \\
\chi^{2} \text { value }\end{array}$ & $\begin{array}{l}\text { Degrees } \\
\text { of freed. }\end{array}$ & $\begin{array}{l}\text { Probability } \\
\text { level for } \\
\text { rejection }\end{array}$ \\
\hline $\begin{array}{c}\sigma^{x} \text { adults } \\
\text { winter-spring } \\
\text { o adults }\end{array}$ & 0.423 & 0.70 & 4.23 & 1 & $P<0.05$ \\
\hline $\begin{array}{c}\text { winter-spring } \\
\sigma^{T} \text { adults }\end{array}$ & 0.617 & 0.62 & 4.72 & 2 & $P<0.1$ \\
\hline $\begin{array}{c}\text { summer-autumn } \\
\text { o adults }\end{array}$ & 0.650 & 0.61 & 4.23 & 1 & $P<0.05$ \\
\hline $\begin{array}{l}\text { summer-autumn } \\
K-1 \text { cohort } \\
K-2 \\
K-3\end{array}$ & $\begin{array}{l}3.00 \\
2.032 \\
3.345 \\
1.743\end{array}$ & $\begin{array}{l}0.25 \\
0.33 \\
0.23 \\
0.36\end{array}$ & $\begin{array}{l}1.73 \\
1.47 \\
4.26 \\
4.20\end{array}$ & $\begin{array}{l}3 \\
3 \\
4 \\
3\end{array}$ & 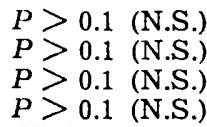 \\
\hline
\end{tabular}

trappability in winter and spring (0.7 to 0.9$)$ than in summer and fall (arouna 0.5). The value for the January 1972 kill trapping was derived from the regression density estimation method of Hayne (1949 a) (see Appendix I). Data of individual trappability, pooled per cohort and season, show that the difference between winter-spring and summer-fall values is due to a decrease of adult female's trappability in summer, and to the appearance of less trappable young (Table 4). Homogeneity 
of probability of capture across the individuals of a same cohort within each season, was tested by comparing the observed distribution of numbers of "failures « between successive captures (see Appendix I), to a Geometric probability distribution (Fig. 10); this law should fit if all individuals in the cohort and season have a constant and identical probability of capture (Seber, 1973; Appendix I). The Geometric law was rejected for all cohorts in winter-spring, and for adult males in summer-fall (Table 4). As the mean number of »failures" between first and second-, second and third- capture etc... did not seem to fluctuate

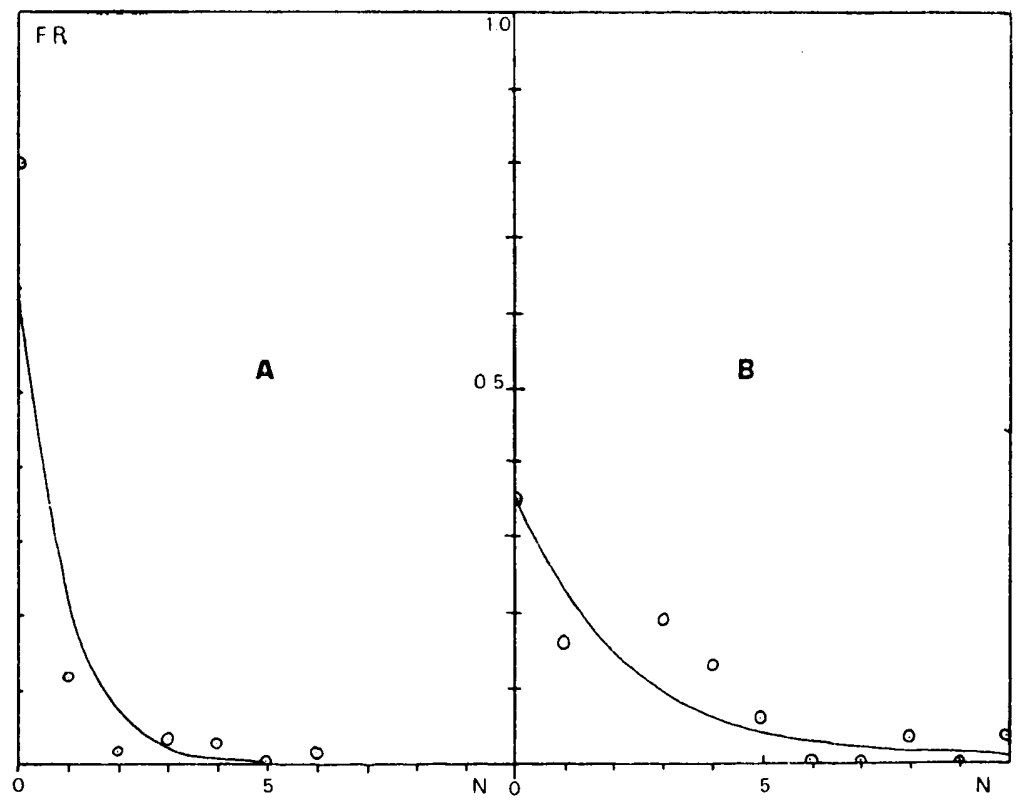

Fig. 10. Observed (points) and expected (continuous lines) distributions of the number of trapping occasions separating two successive captures (N) for two cohorts on the intensive plot, 1971.

Fr: relative frequency. A: adult males (cohorts $K-69-K-70$ ), winter-spring: significant departure from Geometric distribution. B: K-1 cohort, summer-autumn: agreement between observed and expected distributions.

differently in those groups leading to rejection and those leading to acceptance of the Geometric law (Fig. 11), we conclude that heterogeneity of probability of capture in winter-spring and among males in summer-fall, is due to interindividual differences in trappability. Whence we conclude that males and females in winter-spring group individuals with differing probabilities of capture, while adult females and young cohorts in summer-fall are homogeneous. 


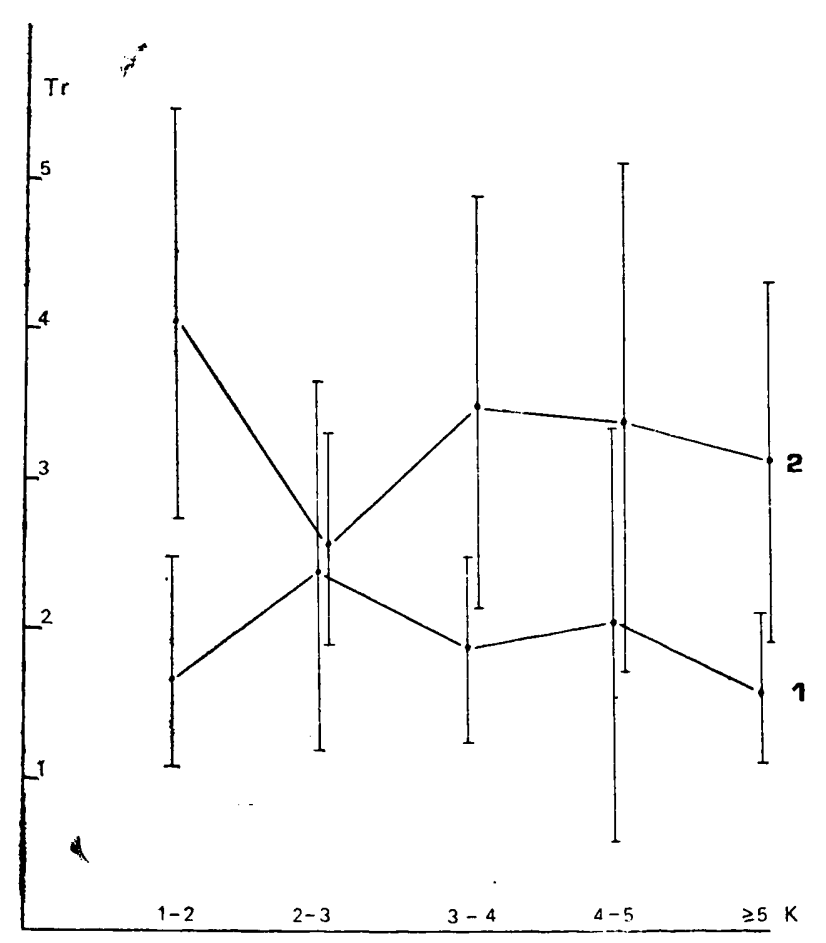

Fig. 11. Mean number of trappings ( $\mathrm{Tr}$ : Appendix 1) between successive pairs of captures, for the individuals leading to rejection (1) and to acceptance (2) of homogeneity of probability of capture.

Vertical bars: $95 \%$ c.i. $K$ : pair of successive captures. For (1): effect of $K$ is significant $\left(F_{4,148}=3.20\right)$, due only to non homogeneous variance in the $K \geqslant 5$ group (without this group: $F_{3,72}=0.10$ ); for (2) effect of $K$ non significant $\left(F_{4,86}=1.34\right.$ ).

\section{DISCUSSION}

\subsection{Critique of the Density Estimation Methods}

We first compare the applicability of the Manly-Parr (M.P) and the Modified Calendar of Captures (M.CC.) methods of density estimation to our data.

The successive summer density rises are revealed about a month later by M.P. than by M.CC. method. The dynamics of numbers of the young-of-the-year cohorts as obtained by the M.CC. method, are coherent with the independent natality estimations (see interpolations between first density estimations and estimated natality on Fig. 4), whence it may be concluded that the latter method correctly follows the density rise due to reproduction. The time lag observed with the M.P. method may be attributed to non trappability of young before the age of 1 month (Fig. 3). 
$M . P$. and equivalent methods assume constant probability of capture, which hypothesis is obviously falsified in this study ( $\$ 3.4 .4$.); as already noted by many authors for many small mammal species (Crowcroft \& Jeffers, 1961; Tanaka, 1963, Kikkawa, 1964; Sheppe, 1967; Andrzejewski et al., 1967; Brown, 1969; Watts, 1970). The M.CC. method assumes a negligibly small probability of an individual remaining undiscovered; this may be considered true for adults present since the 1971 winter Fnd for young ones still alive at the age of 3 moniths ( $\S 3.4 .4$.). In order to estimate the mortality of young before first capture, it also assumes an equal mortality rate of marked and unmarked ones, which is certainly sounder than the hypothesis of equitrappability. The M.CC. method finally relies on estimated residency times (Appendix I), which, owing to the high individual trappability, are generally close to the cbserved residency times (Table 6).

In the January 1972 trapping series, we observe a discrepancy between the density estimations by the M.CC. and the Hayne (1949 a) methods (23 vs. 28 individuals). This is due to an increased probability of remaining undiscovered, for those individuals joining the plot towards the end of the CMR experiment. During control trapping in February 1972, 4 unmarked individuals were captured on the intensive plot; as the extermination campaign around this plot was terminated by end January, these individuals are unlikely to have immigrated after the January trapping series and probably are fall-immigrants which remained undiscovered through the January trapping. Whence the insufficiency of the M.CC. method at the end of the CMR experiment was corrected in the present study by the final extermination campaign.

The above discussion justifies the fact that population dynamics was based on the results of the M.CC. method. This method could not be applied to the 1970 data, because of irregular trapping schedule, absence of trapping in summer and impossibility to distinguish between native and immigrant young ones. Moreover, Tanaka $(1961,1970)$ showed that trap distance should be less than half the home range length in order that all the population be exposed to trapping, which was not the case in fall 1970 with fixed $1.5 \mathrm{~km}$. distance between trap-groups. Whence only spring 1970 data were used for some points of comparison with 1971 data, based on the minimum numbers known to be present (Fig. 5).

\subsection{Population Regulation}

Before discussing the potential action of regulating mechanisms, winter density of our population may be compared to the bibliographic data compiled in Table 5 . Winter was chosen because most published data refer to this season, and this is the most stable season of the year. 
These data should only be compared on an order of magnitude basis, because of important methodological disparity between studies. The population in our study stands rather on the lower edge, with densities comparable to those found in coastal marshes (Blackwater Refuge, Maryland: Dozier et al., 1948) or Northern U.S. marshes (Sand lake Refuge, S.-Dakota: Aldous, 1947). But there seems to be no reason for considering it as overcrowded or very scarce. The action of regulating mechanisms is suggested by the following outstanding events: (a) coristancy of winter population density over 3 years; (b) increase of disappearance rate during a short spring period (Fig. 4, 5) (46\% disap-

Table 5

Published densities of muskrats, per hectare.

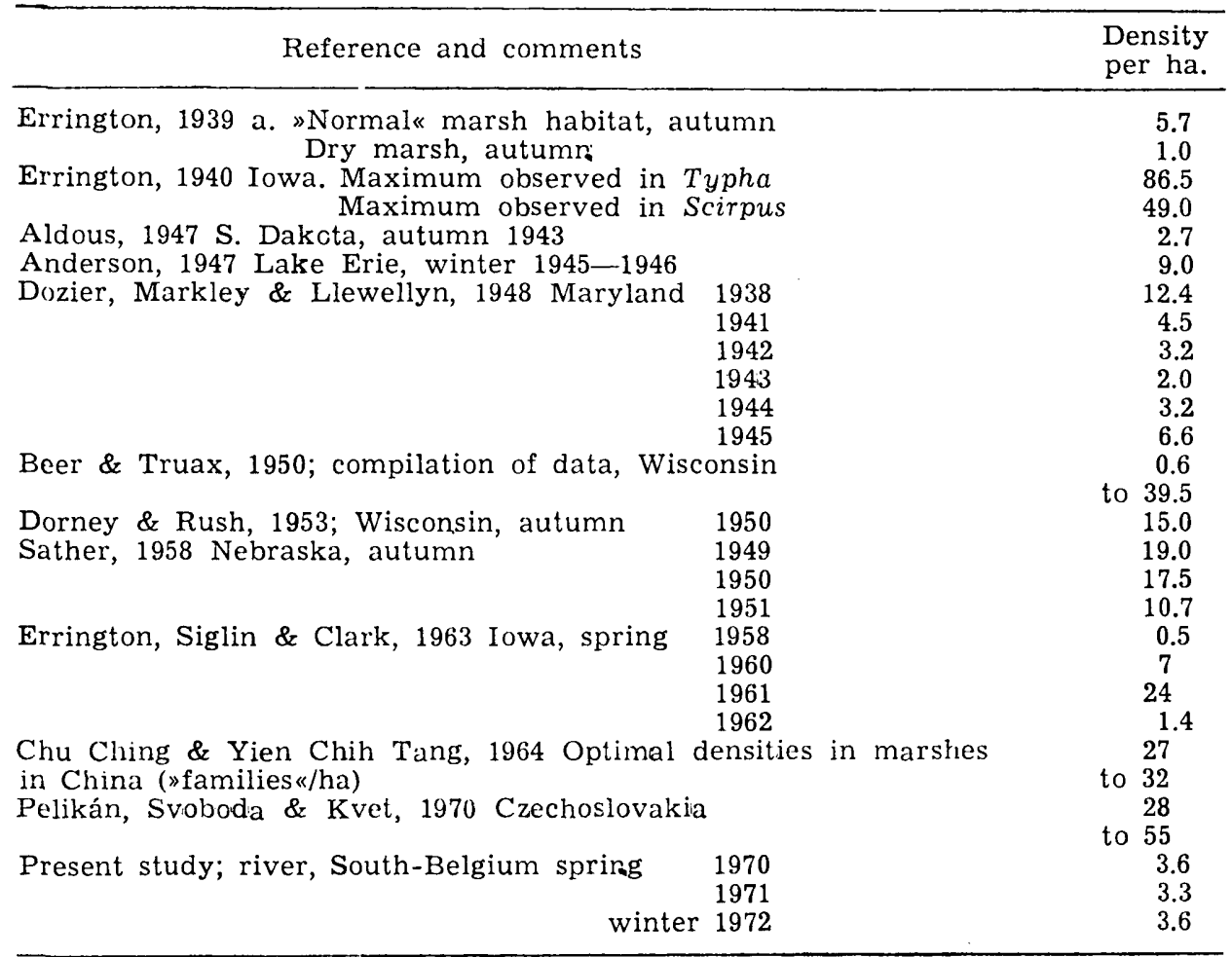

pearance: $21 \%$ through emigration and $25 \%$ through death) selectively affecting the first-year adult cohort (64\% disappearance vs. $1 / 6$ for old adults). After spring all adults suffer a low mortality rate and become very sedentary; (c) heavy and cohort-specific mortality of young-of-theyear; younger cohorts suffer a higher mortality than older ones (Fig. 4, Table 2). 
In a search for factors which could explain the above phenomenc, we first examine the extrinsic ones: climate, food, predation, disease and parasitism.

Climate may directly affect muskrat population dynamics (see Le Boulenge, 1972), but the conditions for this to happen (see Introduction) are rarely met in Belgium and were not observed in this study: ponds were frozen for $2-3$ weeks per year, with a maximum ice-depth of $30 \mathrm{~cm}$.; rainfall was normal $\left(1005 \mathrm{~mm}\right.$./year ${ }^{1}$ for Belgium; 2 floods were observed in the river: the first, sudden but brief, in March 1970 and the second, moderate, in January 1971. No summer drought occurred during the study years. Whence it seems in this study, a direct influence of climate on mortality may be ruled out. Food in the river is more scarce than ir ponds (reflected in the difference of home range sizes: 0.7 to 0.9 ha. in our study, as compared to 0.2 to 0.4 ha. in ponds: Sather, 1958; Erickson, 1963; Neal 1968), and consists mainly of terrestrial plants (Graminae, Urtica spp.) and sometimes Juncus effusus and Iris pseudacorus. This food supply strongly diminishes in winter, but in this season there is plenty of dead tree leaves (Alnus sp., Fraxinus sp., Salix sp., Corylus avellana, Sorbus sp.), which we observed muskrats to eat in captivity. Owing to the versatility of their feeding habits, Errirgton (1948) argued that muskrats should be quite insensitive to the quantity of their preferred aquatic plant species. In the absence of quantitative data, at least we never had the impression of scarcity of food, nor did we observe starving animals, except for one female starving due to broken incisors (weight fluctuations in Fig. 6).

Likely predators of muskrats were rare on the study plot. Mammal predators (Mustela putorius, Lutra lutra, Vulpes vulpes, feral dogs and cats) were actively pursued by hunters and foresters. Avian predators (5-6 Buteo buteo and several Stryx aluco observed on the plot) probably could hunt only on young muskrats.

One clear case of predation pressure was observed on the extensive study plot, when in a small creek and 4 associated ponds bearing abundant evidence of muskrat presence, we captured 2 polecats and no muskrats. Potential importance of predation should not be discarded, but as stated by Errington (1943) predation probably affects individuals condemned to premature death from other causes. No symptoms Errington's disease or tularemia, the most well known diseases in muskrat, were discovered during our study. On the other hand, $67 \%$ of the river muskrats we dissected beared internal parasites of the genus Taenia sp. encysted in the liver or more rarely in the peritoneal cavity.

1 source: Inst. Roy. Météorol. Belg., Bull. mens., 1970-1971. 
Parasitized individuals had on an average 3.5 cysts, with a maximum of 65 in a young muskrat whose liver had shrunk to half the normal volume. Arata (1959) quoted some studies where such a high incidence of parasitism has been observed. Most animals dying in our live-traps were parasitized, suggesting parasitism may affect survival.

These obsrvations show that several extrinsic factors may have influenced the population dynamics on our study plot, but it is difficult to imagine how they might be related to the peculiar trends we observed: spring mortality and emigration, and selective mortality rate in the cohorts of young. Whence we now examine the particularities of the cohorts in relation to population dynamics.

Several events were contemporaneous with the spring decline period and might be related to it: (a) reproduction activity started simultaneously with it; some females started reproducing about one month earlier than the others, the former producing $K-1$ young and the later, $K-2$ young. (b) Males entered their only aggressive period of the year, while establishing and defending territories. Spring territoriality is very Eenerally observed in male muskrats, and many authors presume it is associated with reproductive activity (Errington, 1939 b; Lay, 1945; Aldous, 1947; Beer \& Meyer, 1951; Mathiak, 1966; Akkerman, 1975). In one case, we observed the replacement of a K-69 male by another, bigger, $K-69$ male on its range, the former shifting its range and bearing several injuries after this event. Indirect evidence suggests females also started defending territories in this period: overlap of their home ranges, pronounced in winter and early spring, almost vanished by the end of April (Fig. 8). Moreover, we observed them to be very intolerant in captivity throughout the reproduction period. Evidence for such a phenomenon in female muskrats is given by Akkermann (1975), and in female Arvicola terrestris by Stoddart $(1970$ a). (c) Trappability was heterogenous among males and females in this period (Table 4). According to Andrzejewski et al. $(1967,1971)$ and Gliwicz (1970) such heterogeneity would reflect differences in social status of the individuals. Indeed, mostly young adults $(K-70)$ disappeared from the field. (d) Emigration occurring in this period was not compensated for by immigration; injuries were observed in dispersing individuals, and some started moving after being chases from their range (see also Akkermann, 1975). It seems this kind of dispersal corresponds to the "saturation dispersal " concept of Lidicker (1973).

These elements may be interpreted as indicating a competition for obtaining reproduction territories, among males as well as females (Chu Ching \& Yien Chih Tang, 1964, indirectly suggests this by indicating a close relationship between density of muskrats and the ratio of length 
of fit shoreline to extent of water surface): A hierarchy seemed to establish among the individuals in spring, with »subdominant « ones being forced to emigrate or to die, and some females showing delayed reproduction. Although ultimate factors are not known, it seems these processes would constitute a limitating mechanism of natality. Such a mechanism of natality limitation has been put forward by Bujalska (1970) for an isolated population of Clethrionomys glareolus.

In relation with this critical spring period, we would like to discuss the so-called »spring dispersal" in muskrats. Many authors admit that muskrats engage in a "spring dispersal " or "spring migration" (e.g. Errington, 1939 b, 1940, 1943; Spruegel, 1951; Shanks \& Arthur, 1952;; van Wijngaarden, 1955; Sather, 1958; Erickson, 1963). In the light of our results, this concept seems to be overemphasized. In fact, gonadotropic activity increases in spring, perhaps following the increase in day length (Beer \& Meyer, 1951), or in accordance with climatic changes (Spruegel, 1951; Van Wijngaarden, 1955; Olsen, 1959; Erickson, 1963). So in this period (mid-March- mid-April), animals are "physiologically ready to reproduce" (Beer \& Meyer, 1951). This in turn urges the establishment of reproduction territories (Errington, 1940; Beer \& Meyer, 1951; Spruegel, 1951; Erickson, 1963; Akkermann, 1975) and formation of bisexual pairs (Shanks \& Arthur, 1952; Van Wijngaarden, 1955). Whence, as observed in this study, part of the individuals have no other alternative than either being exposed to immediate hazards of death from predation, prolonged attacks by congeners or exposure to climatic constraints, or to emigrate. But it seems difficult to agree with Beer \& Meyer (1951), that muskrats are "psychologically ready to move" (see Akkermann, 1975). In our view, part of them is just forced to. We are conforted in our interpretation by the following arguments: (a) The proportion of dispersing individuals is generally small (Warwick, 1940; Beer \& Truax, 1950; Mathiak, 1966, Mallach, 1971). If there is competition for reproduction territories, we would expect this proportion to be variable, but the number of territories (or pairs) to remain quite constant from year to year in the same field, as observed in our data. Unfortunately, data are still lacking to show the generality of this (see Bujalska, 1970). (b) Erickson (1963) observed spring dispersal periods of 45, 36 and 42 days on three consecutive years. This length quite precisely corresponds to the period of increased disappearance rate in the present study on two consecutive springs, when one could have the impression of dispersal. (c) Errington (1943), Sather (1958) and Akkermann (1975) cbserved a high proportion of wounded animals in the spring migrants; this is what would be expected of individuals forced to move in a situation of saturation dispersal, as observed in the present study. (d) 
One would expect that if spring dispersal was the fate of animals $\gg$ ready io move«, emigrations as well as immigrations would be observed, which in our data at least is not so. As a conclusion, we believe spring dispersal in muskrats is just a manifestation of a natality limitating mechanism acting in that period.

The second critical period occurs in summer, when the peak population density resulting from reproduction, is reduced through mortality of young. This mortality increases from the oldest to the youngest cohort. It seems that this difference is not the result of depleted food supply because the growth curves of the cohorts of young are very similar. Considering the differences in home range size, we might hypothesize that the oldest cohort members, becoming first independent from the parents, establish themselves in the most suitable places next to the parental burrows, while the younger cohorts are obliged to search farther away for a place to live. Better success of spring-born young is also shown for Arvicola terrestris by Stoddart (1970 b). We think autumn and spring dispersal are of a different kind. Spring dispersal is one-way (emigration), with low survival of emigrants; in autumn, emigration and immigration are numerically equivalent and survival of emigrants is high. Spring dispersal might be related to the "saturation dispersal « described by Lidicker (1973) while the autumn one would be of the "presaturation " type, resulting in a "reshuffling" of the population components.

To corclude, our observations suggest year-to-year stability of the winter population is maintained through the action of two regulating mechanisms, the first being competition in males and females for reproduction territories in spring and the second, a differential mortality of the successive cohorts of young, perhaps originating in a competition for suitable burrows.

Acknowledgements: This work is part of a Ph. D. thesis by Eric Le Boulengé at the Universite Catholique de Louvain. Among the many persons and institutions who helped us through this work, we especialy like to thank: Professors P. Berthet and G. Gérard; the members of the Population Department of the Institute of Ecology of the Polish Academy of Sciences, particularly Professors K. Petrusewicz and R. Andrzejewski and Drs, K. Andrzejewska and M. Mazurkiewicz: the Belgian Ministry of Agriculture; the Chief State trapper J. Javaux; Mr. $J$. Brahy and P. Grenez and their families, for housing us and helping us on the field; Mr. E. Jal and Mrs. M. Vanderbeck, for preparing the figures and typing the text. This study was supported partly by a 3-year grant from the IRSIA, partly by an 8-months grant from the Polish Ministry of Culture.

\section{REFERENCES}

1. Akkermann R., 1973: Markiorungsmöglichkeiten des Bisams (Ondatra zibethicus, L.). Zeitsch. f. Angewante Zool., 60: 480-493.

2. Akkermann R., 1975: Untersuchungen zur Okologie und Populationsdynamik 
des Bisams (Ondatra zibethicus, L.) am einem nordwestdeutschen Verlandurgssee. Zeitsch. f. Angewante Zool., 62: 39-81.

3. Aldous S. A., 1947: Muskrat trapping on Sand lake Nat. Wildl. Ref. - Scuth Dakota. J. Wildl. Manage., 11: 77-90.

4. Andrzejewski R., 1963: Processes of incoming, settlement and disappearance of individuals and variations in the numbers of small rodents. Acta theriol., 7: 169-213.

5. Andrzejewski R., 1969: Analysis of catches of small mammals by the "Caiendar of Catches" method. Zeszyty nauk., 2: 1-104, Inst. Ekologii PAN. [in Polish, with English summary].

6. Andrzejewski R., Petrusewicz K. \& Waszkiewicz-Gliwicz J., 1967: The trappability of Clethrionomys glareolus (Schreber, 1780) and other ecological parameters obtained by the C.M.R. capture method. Ekol. pol., Ser. A, 15: $709-725$.

7. Andrzejewski R., Fejgin H. \& Liro A., 1971: Trappability of trap-prone and trap-shy bank voles. Acta theriol., 16: 401-412.

8. Applegate V. C. \& Predmore H. E. Jr., 1947: Age classes and patterns of primeness in a fall collection of muskrat pelts. J. Wild. Manage., 11: $324-330$.

9. Arata A. A., 1959: Ecology of muskrats in strip-mine ponds in Southern Illinois. J. Wildl. Manage., 23: 177-186.

10. Baumgartner L. L. \& Bellrose F. C., 1943: Determination of sex and age in muskrats. J. Wildl. Manage., 7: 77-81.

11. Beer J. R. \& Truax W., 1950: Sex and age ratios in Wisconsin muskrats. J. Wildl. Manage., 14: 323-331.

12. Beer J. R. \& Meyer R. K., 1951: Seasonal variations in the endocrine organs of the muskrat. J. Mammal., 32: 173-191.

13. Bellrose F. C. \& Brown L. G., 1941: The effect of fluctuating water levels on the muskrat population of the Illinois River Valley. J. Wildl. Manage., 5: 206-212.

14. Bellrose F. C. \& Low J. B., 1943: The influence of flood and low water levels on the survival of muskrats. J. Mammal., 24: 173-188.

15. Beshears N. \& Haugen A., 1953: Muskrats in relation to farm ponds. J. Wildl. Manage., 17: 450-454.

16. Brown L. E., 1969: Field experiments on the movements of Apodemus sylvaticus (L.) using trapping and tracking techniques. Oecologia, 2: 198-222.

17. Bujalska G., 1970: Reproduction stabilizing elements in an island population of Clethrionomys glareolus (Schreber, 1780). Acta theriol., 15: 381-412.

18. Chappelier A., 1933: Lutte contre le Rat Musqué. Collection des monogr., Inst. Rech. Agron.

19. Chitty D. \& Phipps E., 1966: Seasonal changes in survival in mixed populations of two species of vole. J. Anim. Ecol., 35: 313-331.

20. Chu Ching \& Yien Chih Tang, 1964: Habitats and densities of the muskrat, Ondatra zibethica (L.). Acta Zool. Sinica, 16: 354-371. [in Chinese with English summary].

21. Chu Ching \& Yien' Chih Tang, 1965: Foods and food bases of the Muskrat. Ondatra zibethica (L.). Acta Zool. Sinica, 17: 352-363. [in Chinese with English summary].

22. Crowcroft P. \& Jeffers J. N. R., 1961: Variability in the behaviour of wild house-mice (Mus musculus, L.) toward livetraps. Proc. Zool. Soc. Lond., 137: 573-582. 
23. , Dice L. R. \& Clark P. J.,; 1953: The statistical concept of home range as applied to recapture radius of the deermouse (Peromyscus). Contr. Lab. Verteb. Biol. Univ. Mich., 62: 1-15.

24. Dorney R. S. \& Rush A. J., 1953: Muskrat growth and litter production. Tech. Wildl. Bull., 8: 4-32.

25. Dozier H. L., Markley M. H. \& Llewellyn L. M., 1948: Muskrat investigations on the Blackwater National Wildlife Refuge, 1941-1945. J. Wildl. Mange., 12: $177-190$.

26. Erickson H. R., 1963: Reproduction, growth and movement of Muskrats inhabiting small water areas in' New-York State. N.-Y. Fish \& Game J., 10: $80-117$.

27. Errington P. L., 1937: The breeding season of the muskrat in North western Iowa. J. Mammal., 18: 333-337.

28. Errington P. L., 1939 a: Observations on young muskrats in Iowa. J. Mammal. 20: $465-478$.

29. Errington: P. L., 1939 b: Reactions of muskrat populations to drought. Ecology, 20: $168-186$.

30. Errington P. L., 1940: Natural restocking of muskrat-vacant habitat. J. Wildl. Manage., 4: 173--185.

31. Errington P. L. 1943: An analysis of Mink predation upon Muskrats in North-Central United States. Res. Bull., Agr. Exper. Sta., Iowa State Coll., Agr. \& Mech. Arts., 320: 798-924.

32. Errington P. L., 1948: Environmental control for increasing Muskrat production. Trans. Nat. Am. Wildl. Conf., 13: 596-609.

33. Errington P. L., 1963: Muskrat populations. Iowa State Univ. Press: 1-665.

34. Errington P. L., Siglin R. J. \& Clark R. C., 1963: The decline of a muskrat population. J. Wildl. Manage., 27: 1-8.

35. Gliwicz J., 1970: Relation between trappability and age of individuals in a population of the bank vole. Acta theriol., 15: 15-23.

36. Hansson L. \& Andersson M., 1975: Factors governing small rodent outbreaks - a review of the development and implications of some hypotheses. [In: "Biocontrol of Rodents", Ed. L. Hansson and B. Nilsson], Ecol., Bull., 19: $151-162$.

37. Hayne D. W., 1949 a: Two methods for estimating population from trapping records. J. Mammal., 30: 399-411.

38. Hayne D. W., 1949 b: Calculation of size of home range. J. Mammal., 30: 1-18.

39. Jolly G. M., 1965: Estimates of population parameters from multiple recapture with both death and immigration. Stochastic model. Biometrika, 52: $225-247$.

40. Kikkawa J., 1964: Movement, activity and distribution of the small rodents Clethrionomys glareolus and Apodemus sylvaticus in woodland. J. Anim. Ecol., 33: 259-299.

41. Krebs C. J., 1972: Ecology. The experimental analysis of distribution and abundance. Harper and Row: 1-694. New-York.

42. Lavrov N. P., 1957: Fluctuations and forecasts of muskrat numbers. Russian Game Report, Can. Wildl. Serv.: 202-223.

43. Lay D., 1945: Muskrat investigations in Texas. J. Wildl. Manage,, 9: 56-76.

44. Le Boulengé E., 1972: Etat de nos connaissances sur l'écologie du rat musqué, Ondatra zibethica (L.). La Terre et la Vie, 1 : $3-37$.

45. Le Boulengé E., 1977: Two ageing methods for muskrats: live or dead animals. Acta theriol., 22: 509-520. 
46. Lidicker W. Z. Jr., 1973: The role of dispersal in the demography of smail mammals. IVème Symp. "Small Mammal Working Group" Warszawa, Nor. 1973: $1-44$.

47. Mallach N., 1971: Markierungsversuche zur Analyse des Aktionsraum und der Ortbewegungen des Bisams (Ondrata zibethica L.). Anz. f. schädlingsk 2 . Pflanzenschutz, 44: 129-136.

48. Manly B. J. F. \& Parr M. J., 1968: A new method of estimating populatio. size, survivorship and birth rate from capture-recapture data. Trans. Soc. Brit. Entom., 18: 81-89.

49. Mathiak H. A., 1966: Muskrat population studies at Horicon marsh, Wisconsir.. Wisc. Cons. Dept., Tech. Bull., 36: 1-56.

50. Mazurkiewicz M., 1969: Elliptical modification of the home range pattern. Bull. Acad. Pol. Sci., Cl. II. 17: 427-431.

51. Moens R., 1961: Méthodologie des observations effectués sur le terrain au cours des recherches sur le Rat musqué. XIII Symp. Phytopharm. \& Phytiatr., Gand, Belgium.

52. Moens R., 1978: Etude bioécologique du Rat Musqué en Belgique. Parasitica, 34: $57-121$.

53. Mohr C. O., 1965: Calculation of area of animal activity by use of median axes and centers in scatter diagrams. Res. Pop. Ecol., 7: 73-86.

54. Neal T. J., 1968: A comparison of two muskrat populations. Iowa St. Jour. Sci., 43: 193-210.

55. Olsen P., 1959: Muskrat breeding biology at Delta, Manitoba. J. Wildl. Manage., 23: $40-53$.

56. Pelikán J., 1969: Testing and elimination of the edge effect in trapping small mammals. [In: "Energy flow through small mammal populations", Eds. K. Petrusewicz \& L. Ryszkowski]: 57-61. PWN, Warszawa.

57. , Pelikán J., Svoboda J. \& Kvet Jł; 1970: On some relations between the production of T'ypha latifolia and a muskrat popultation. Zool. listy, 19: 303-320.

58. Petrusewicz K. \& Macfadyen A., 1970: Productivity of terrestrial animals. IBP Handbook $\mathrm{n}^{\circ}$ 13. Blackwell Scient. Public.: 1-190. Oxford and Edinburgh.

59. Sather J. H., 1958: Biology of the Great-Plains muskrat in Nebraska. Wildl. Monogr., 2: 1-35.

f.0. Seber G. A. F., 1973: The estimation of animal abundance and related parameters. Ch. Griffin and Co.: $1-506$.

60. Shanks C. E. \& Arthur G. C., 1952: Muskrat movements and population dynamics in Missouri farm ponds and streams. J. Wildl. Manage., 16: 138-148.

61. Sheppe W., 1967: The effect of live-trapping on the movements of Peromyscus. Amer. Midl. Nat., 78: 471-480.

62. Smith M. H., Gardner R. H., Gentry J. B., Kaufman D. W. \& O'Farrel M. J., 1975: Density estimations of small mammal populations. [In: "Small mammals, their productivity and population dynamics", Eds. Golley F. B., Petrusewicz K. \& Ryszkowski, L.]. I.B.P., 5: 25-53. Cambridge Univ. Press, Cambridge.

63. Spruegel G. Jr., 1951: Spring dispersal and settling activities of Central Iowa Muskrats. Iowa St. Coll. J. Sci., 26: 71-84.

64. Stoddart D. M., 1970 a: Individual range, dispersion and dispersal in a population of water voles (Arvicola terrestris L.). J. Anim. Ecol., 39: 403-425.

65. Stoddart D. M., 1970 b: Breeding and survival in a population of water voles. J. Anim. Ecol., 39: 487-494. 
66. Tanaka R., 1961: A field study of effect of trap spacing upon estimates of ranges and populations in small mammals by mean's of a Latin square arrangement of traps. Bull. Kochi Women Univ. Ser. Nat. Sci., 9: 8-16.

67. Tanaka R., 1963: On the problem of trap-response types of small mammal populations. Res. Pop. Ecol., 5: 139-146.

68. Tanaka R., 1970: A field study of the effect of prebaiting on censusing by the capture-recapture method in a vole population. Res. Pop. Ecol., 12: $111-125$.

69. Tanaka R., 1972: Investigations into the edge effect by use of capture-recapture data in a vole population. Res. Pop. Ecol., 13. 127-151.

70. Van Wijngaarden A., 1955: De bestrijding van' de Muskrat in Nederland. Vakbl. Biol., 35: 68-72.

71. Vincent J-P. \& Quéré J-P., 1972: Quelques données sur la reproduction et sur la dynamique des populations du Rat Musqué Ondatra zibethica (L.) dans le Nord de la France. Ann. Zool. Ecol. Anim., 4: 395-415.

72. Warwick T., 1940: A contribution to the ecology of the Muskrat (Ondatra zibethica) in the British isles. Proc. Zool. Soc. London, A 110: 165-201.

73. Watts C.H.S., 1970: A field experiment on intraspecific interactions in the Red-backed vole, Clethrionomys gapperi. J. Mammal., 51: 341-347.

$A=$ cepted, September 15, 1980.

\section{APPENDIX I}

The Modified Callendar of Capture Method

In this section, we explain the modified Calendar of Captures density estimation, together with some information concerning trappability. Capture-recapture data during the 1971 year of the spring-born cohorts, $K-1$ and $K-2$, will be used as an illustration.

\section{Al. Capture-Recapture Matrix, Trappability, Recapture Time}

The capture-recapture data may be arranged into a matrikx $x$, with lines representing the individuals and columns, the trapping days (Table 6). We use the following symbolism:

$X_{i j}=2$ : first or last capture of $i$-th individual on day $j(1 \leqslant i \leqslant N ; 1 \leqslant j \leqslant S)$

$=1$ : recapture (except last) of $i$-th in'dividual on day $j$

$=0$ : non capture, between first and last capture

$=\Theta:$ as 0 , but with no trap available to $i$-th individual on day $j$

$=$ blank: trapping days before first or after last capture of $i$-th individual.

For the time being, let us consider the-symbols in Table 6 , as synonymous of blank. The $\Theta$ symbol, with a value less than 0 but higher than blank, has been introduced to take into account trapping irregularities and our knowledge of spatial behaviour: for example, individual tagged no. 1307 in Table 6 started a dispersal movement of $1.9 \mathrm{~km}$. downwards the river on trapping series 8 ; no traps were set on its daily trajectory (assumed constant) on last day of series 8 and 11 and on series 9. These were thus considered as "non trapping " days for that individual and given symbol $\Theta$ in Table 6 .

Further, we will use the Boolean operator:

$F(=(X \leftrightarrow x)$ where $\leftrightarrow$ stands for a logical comparison operation $(<\rangle,,=$ $\neq \ldots) ; F=1$ if the comparison is true, $=0$ otherwise. 
Table 6

Capture-recapture matrix E, captured as emigrant; + , dead at last

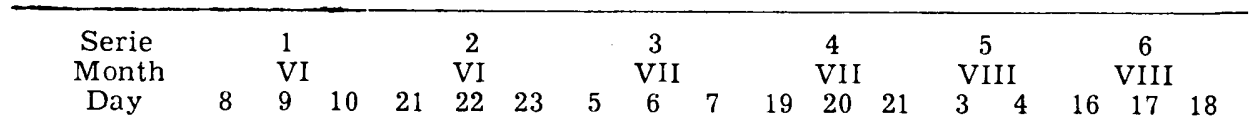

\begin{tabular}{|c|c|c|c|c|c|c|c|c|c|c|c|c|c|c|c|c|c|c|c|}
\hline 1310 & $F$ & K2 & - & 2 & - & - & - & - & - & & & & & & & & & & \\
\hline 1309 & ? & $K 2$ & - & - & 2 & - & - & - & - & - & & & & & & & & & \\
\hline 1307 & $\mathrm{M}$ & $K_{1}$ & - & - & - & 2 & 1 & 1 & 0 & 1 & 1 & 0 & 1 & 1 & 1 & 1 & 1 & 0 & 1 \\
\hline 1304 & M & $K_{1}$ & - & - & - & - & 2 & 0 & 0 & 1 & 0 & 0 & 0 & 0 & 1 & 0 & 0 & $2+$ & \\
\hline 1306 & $\mathrm{~F}$ & $K 2$ & - & - & - & - & 2 & 0 & 0 & 0 & 0 & 0 & 0 & 0 & 0 & 0 & 1 & 0 & 0 \\
\hline 1508 & M & $K_{2}$ & - & - & - & - & - & - & 2 & 0 & 0 & 0 & 0 & 4 & 0 & 1 & 0 & 0 & 0 \\
\hline 1507 & $\mathrm{M}$ & $K 2$ & - & - & - & - & - & - & - & - & 2 & 0 & 1 & 1 & 1 & 1 & 0 & 1 & 1 \\
\hline 1501 & $F$ & $K_{1}$ & - & - & - & - & - & - & - & - & - & 2 & 1 & 0 & 1 & 0 & 0 & 1 & 0 \\
\hline 711 & $\mathrm{M}$ & $K 2$ & - & - & - & - & - & - & - & - & - & 2 & 0 & 0 & 0 & 0 & 0 & 0 & 0 \\
\hline 1709 & $\mathrm{M}$ & K2 & - & - & - & - & - & - & - & - & - & 2 & 0 & 0 & 1 & 0 & 1 & 0 & 0 \\
\hline 1710 & $F$ & K2 & - & - & - & - & - & - & - & - & - & 2 & 0 & 0 & 0 & 1 & 0 & 0 & 1 \\
\hline 1708 & $?$ & $K 2$ & - & - & - & - & - & - & - & - & - & - & - & 2 & - & - & - & - & - \\
\hline 1606 & $\mathrm{~F}$ & $K 2$ & - & - & - & - & - & - & - & - & - & $\ldots$ & - & - & 2 & 0 & 0 & 1 & 0 \\
\hline 1609 & $\mathrm{M}$ & $K 2$ & - & - & - & - & - & - & - & - & - & - & - & - & 2 & 2 & 0 & 0 & 2 \\
\hline 1109 & M & $K_{1}$ & - & - & - & - & - & - & - & - & - & - & - & - & - & 2 & 0 & 0 & 0 \\
\hline 1804 & $F$ & $K_{1}$ & - & - & - & - & - & - & - & - & - & - & - & - & - & - & - & - & 2 \\
\hline 1810 & $\mathrm{M}$ & $K 1$ & - & - & - & - & - & - & - & - & - & - & - & - & - & - & $\ldots$ & $\ldots$ & - \\
\hline 0001 & M & $K_{2}$ & - & - & - & - & - & - & - & - & - & - & - & - & - & - & - & $\ldots$ & - \\
\hline 0003 & $?$ & $K 2$ & - & - & - & - & - & - & - & - & - & - & - & - & - & - & - & - & - \\
\hline 1007 & $\mathrm{~F}$ & K2 & - & - & - & - & - & - & - & - & - & - & - & - & - & - & - & - & - \\
\hline 1009 & M & $K_{2}$ & - & - & - & - & - & - & - & - & - & - & - & $\ldots$ & $\ldots$ & - & - & - & - \\
\hline 1010 & M & $K_{1}$ & - & - & - & - & - & - & - & - & - & - & - & - & - & - & - & - & $\ldots$ \\
\hline 1104 & M & $K_{1}$ & - & - & - & - & - & - & - & - & - & - & - & - & - & - & - & - & - \\
\hline 1108 & $F$ & $K 2$ & - & - & - & - & - & - & - & - & - & - & - & - & - & - & - & - & - \\
\hline 0014 & $F$ & $K$ & & & & & & & & & & & & & & & & & \\
\hline 3442 & $F$ & $K_{1}$ & & & & & & & & & & & & & & & & & \\
\hline 3459 & $\mathrm{M}$ & $K_{1}$ & & & & & & & & & & & & & & & & & \\
\hline 475 & M & $h$ & & & & & & & & & & & & & & & & & \\
\hline
\end{tabular}

Using these operators, we have, for example:

$\sum_{i=1}^{N}\left(X_{i j} \geqslant 1\right):$ number of captures on day $j$

$N$

$\sum_{i=1}\left(X_{i j} \geqslant \Theta\right): \begin{aligned} & \text { minimum number known ta be present« on day } j \text { or classical } \\ & \text { Calendar of Captures. }\end{aligned}$ $\sum_{j=1}^{S}\left(X_{i j} \geqslant 1\right):$ number of captures of $i$-th individual.

Basing on $X$ matrix, we may now estimate the "population trappability " $P_{. j}$ by:

(1) $\hat{p}_{. j}=\sum_{i=1}^{N}\left(X_{\mathrm{ij}}=1\right) / \sum_{i=1}^{N}\left(0 \leqslant X_{i j} \leqslant 1\right)$

which is the Manly-Parr estimator. Assuming homogeneous probability of capture and independence across the individuals, confidence intervals for $p . j$ may be 
for $\mathrm{K} 1-\mathrm{K} 2$ cohort in 1971.

capture. Further sympols: see Appendix I.

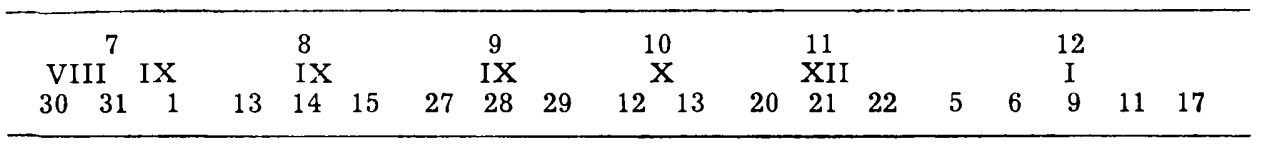

$$
\begin{aligned}
& \mathrm{E}+ \\
& \begin{array}{lllllllllllllll}
0 & 0 & 1 & 1 & 0 & \Theta & \Theta & \Theta & \Theta & \begin{array}{c}
E+ \\
0
\end{array} & 0 & 1 & 0 & \Theta & 2+
\end{array} \\
& \begin{array}{lllllllllllllll}
0 & 0 & 1 & 0 & 0 & 0 & 0 & 0 & 0 & 0 & 0 & 0 & 0 & 1 & 2+ \\
0 & 0 & 2 & - & - & - & - & - & & &
\end{array} \\
& \begin{array}{lllllllllllll}
0 & 0 & 2 & \overline{0} & \overline{0} & \overline{1} & \overline{0} & \overline{0} & 1 & - & \mathbf{E}+
\end{array} \\
& \begin{array}{lllllllllllllllllll}
0 & 0 & 0 & 0 & 0 & 1 & 0 & 0 & 0 & 1 & 0 & 0 & 1 & 0 & 0 & 2+ & & \\
0 & 0 & 0 & 0 & 0 & 0 & 0 & 0 & 0 & 0 & 0 & 0 & 0 & 0 & 0 & 0 & 0 & 0 & 2+ \\
1 & 0 & 0 & 0 & 1 & 0 & 0 & 0 & 0 & 0 & 0 & \Theta & \Theta & \Theta & 2+ & & &
\end{array} \\
& \begin{array}{llllll}
1 & 0 & 0 & 0 & 1 & 0 \\
0 & 2 & - & -
\end{array} \\
& \frac{2}{0} \frac{\overline{0}}{0} \overline{0} \frac{-}{0}
\end{aligned}
$$

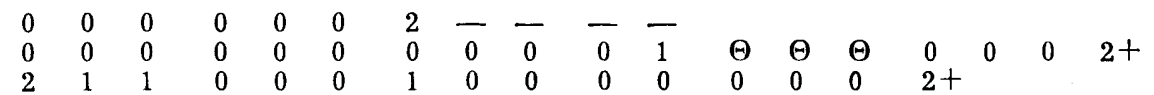

$$
\begin{aligned}
& 211 \\
& \text { 二 } 2 \frac{1}{2}=- \\
& \text { 二- }-\frac{2}{2} \overline{2} \text { - } \overline{2} \text { - }-
\end{aligned}
$$

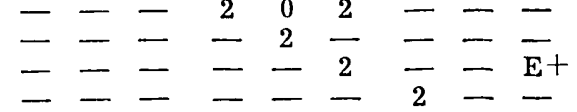

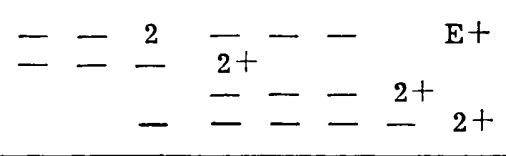

constructed in the classical way for proportions, basing on the Binomial law. Figure 9 illustrates population trappability per trapping series, which is obtained by applying (1) to a reduced $X$ matrix, $X^{\prime}$, where columns are trapping series instead of days, and $X=1$ if $i$-th individual is captured at least once in series $j$. When only daily probability of capture could be obtained, as in the final kill-trapping of January 1972, (daily probability of capture is minus the slope of Hayne's regression line), it was converted into 3-day (series) probability of capture, by:

$$
\hat{\mathrm{p}}(\text { series })=1-1-\hat{\mathrm{p}}(\mathrm{day}))^{8}
$$

Individual trappability as defined in $\S 3.4 .4$. may be estimated by:

(2) $\hat{p}_{i .}=\sum_{j=1}^{S}\left(X_{i j}=1\right) / \sum_{j=1}^{S}\left(0 \leqslant X_{i j} \leqslant 1\right)$

If for a group $G$ of individuals this probability is constant, a pooled group estimate is: 
(3) $\hat{p}_{\mathrm{G} \cdot}: \sum_{i \in G} \sum_{j=1}^{S}\left(X_{i j}=1\right) / \sum_{i \in G} \sum_{j=1}^{S}\left(0 \leqslant X_{i j} \leqslant 1\right)$

Homogeneity of probability of capture may be studied by looking at the distribution of the number of failures to be caught, between pairs of successive captures of an individual (Seber, 1973). If for a group $G$ of individuals homogeneous probability of capture and independence across time and individuals may be assumed, then the $Z_{i k}$ values (number of failures between $k-1$ th and $k$ th captures of $i$ th individual in this group) should be distributed according to a Geometric probability law with parameter $P_{G}$. Two such distribution's are

Table 7

Survival of the marked members of $K 1-K 2$ cohort on the plot in 1971.

A. Table of $n_{j k}$ : individuals appeared at series $k$, still presen't at series $j$.

\begin{tabular}{rllllllllllll}
\hline$k=$ & 1 & 2 & 3 & 4 & 5 & 6 & 7 & 8 & 9 & 10 & 11 & 12 \\
$j=1$ & 2 & & & & & & & & & & & \\
2 & 2 & 3 & & & & & & & & & \\
3 & 2 & 3 & 2 & & & & & & & & \\
4 & 0 & 3 & 2 & 5 & & & & & & & \\
5 & 0 & 3 & 2 & 5 & 3 & & & & & & \\
6 & 0 & 3 & 2 & 5 & 3 & 1 & & & & & \\
7 & 0 & 2 & 2 & 4 & 3 & 1 & 3 & & & & \\
8 & 0 & 2 & 2 & 4 & 3 & 1 & 3 & 4 & & & \\
9 & 0 & 2 & 2 & 3 & 1 & 1 & 2 & 4 & 1 & & \\
10 & 0 & 2 & 1 & 3 & 1 & 1 & 1 & 1 & 1 & 0 & \\
11 & 0 & 2 & 0 & 3 & 0 & 1 & 1 & 0 & 0 & 0 & 3 & \\
12 & 0 & 2 & 0 & 3 & 0 & 1 & 1 & 0 & 0 & 0 & 3 \\
\hline
\end{tabular}

B. Table of $m_{j k}$ : individuals appeared at or before series, $K$, still present at series $j$.

\begin{tabular}{rrrrrrrrrrrrr}
\hline$k=$ & 1 & 2 & 3 & 4 & 5 & 6 & 7 & 8 & 9 & 10 & 11 & 12 \\
$j=1$ & 2 & & & & & & & & & & & \\
2 & 2 & 5 & & & & & & & & & \\
3 & 2 & 5 & 7 & & & & & & & & \\
4 & 0 & 3 & 5 & 10 & & & & & & & \\
5 & 0 & 3 & 5 & 10 & 13 & & & & & & \\
6 & 0 & 3 & 5 & 10 & 13 & 14 & & & & & \\
7 & 0 & 2 & 4 & 8 & 11 & 12 & 15 & & & & \\
8 & 0 & 2 & 4 & 8 & 11 & 12 & 15 & 19 & & & \\
9 & 0 & 2 & 4 & 7 & 8 & 9 & 11 & 15 & 16 & & \\
10 & 0 & 2 & 3 & 6 & 7 & 8 & 9 & 10 & 11 & 11 & & \\
11 & 0 & 2 & 2 & 5 & 5 & 6 & 7 & 7 & 7 & 7 & 10 & \\
12 & 0 & 2 & 2 & 5 & 5 & 6 & 7 & 7 & 7 & 7 & 10 & 11 \\
\hline
\end{tabular}

illustrated in Figure 10. The adequateness of the above hypotheses may thus be verified by a godness-of-fit test (Table 4 ). The average of $Z_{i k}$ variable, $\bar{Z}_{G}$, say, is related to $p_{G}$. by:

(4) $\hat{p}_{G}=1\left(Z_{G}+1\right)$ 
and $T r_{G}=Z_{G}+1$ is the mean number of trappings needed to recapture once a member of group $G$.

If multiplied by the mean number of days between trappings, $T$,

(5) $\mathrm{Tr}_{\mathrm{G}}=\mathrm{Tr} r_{\mathrm{G}} \times \mathrm{T}$

is the "mean section of time between' successive captures" (Andrzejewski, 1963). $\bar{Z}_{G}$ values are presented in Table 4 for all cohorts and seasons during 1971.

\section{A2. Density Estimation}

As in our CMR experiments, trapping days were grouped into series of consecutive days, we will consider a single density estimation per trapping series and per cohort. The first step is to determine each individual's "real"

\section{Table 8}

Modified Calendar of Captures method: calculations of density for $K 1-K 2$ cohort, 1971.

Table $n_{j k}$ (lower triangle), $\hat{n}_{j k}$ (upper triangle) and $\hat{n}_{j}$. (right most column). Symbols: see text (A. 2). In parentheses: number of immigrants appeared at series $k$.

\begin{tabular}{rrrllllllllllllll}
\hline$j$ & Date & $t_{j-1 . j}$ & $k=1$ & 2 & 3 & 4 & 5 & 6 & 7 & 8 & 9 & 10 & 11 & 12 & $\hat{n}_{j .}$. \\
\hline 1 & $9 / 06$ & & 2 & 3.36 & 2.54 & 7.18 & 4.87 & 1.84 & 6.23 & 9.40 & 2.66 & & & 40.1 \\
2 & $22 / 06$ & 13 & 2 & 3 & 2.26 & 6.40 & 4.34 & 1.64 & 5.56 & 8.39 & 2.37 & & & 36.0 \\
3 & $6 / 07$ & 14 & 2 & 3 & 2 & 5.66 & 3.84 & 1.45 & 4.91 & 7.41 & 2.10 & & & 32.4 \\
4 & $20 / 07$ & 14 & 0 & 3 & 2 & 5 & 3.39 & 1.28 & 4.34 & 6.55 & 1.85 & & & 27.4 \\
5 & $3 / 08$ & 14 & 0 & 3 & 2 & 5 & 3 & 1.13 & 3.84 & 5.79 & 1.64 & & & 25.4 \\
6 & $17 / 08$ & 14 & 0 & 3 & 2 & 5 & 3 & 1 & 3.39 & 5.12 & 1.45 & & & 24.0 \\
7 & $31 / 08$ & 14 & 0 & 2 & 2 & 4 & 3 & 1 & 3 & 4.53 & 1.28 & & & 20.8 \\
8 & $14 / 09$ & 14 & 0 & 2 & 2 & 4 & 3 & 1 & 3 & 4 & 1.13 & & & 20.1 \\
9 & $28 / 09$ & 14 & 0 & 2 & $\mathbf{2}$ & 3 & 1 & 1 & 2 & 4 & 1 & & & 16 \\
10 & $12 / 10$ & 14 & 0 & 2 & 1 & 3 & 1 & 1 & 1 & 1 & 1 & 0 & & & 11 \\
11 & $21 / 12$ & 70 & 0 & 2 & 0 & 3 & 0 & 1 & 1 & 0 & 0 & 0 & $(3)$ & & 10 \\
12 & $9 / 01$ & 22 & 0 & 2 & 0 & 3 & 0 & 1 & 1 & 0 & 0 & 0 & 3 & $(1)$ & 11 \\
\hline
\end{tabular}

residency time on the study plot, basing on $X$ matrix. To each individual's cbserved residency time (time span from the first to the last capture), we seek to add an estimation of the time spent on the plot before first- and after lastcapture. In this process, several cases have to be distinguished:

- the individuals known to be born on the plot, have to be considered present since their birthdate, irrespective of the date of first capture.

- The individuals dying or removed at last capture, need not be considered for any additional time after last capture.

For the remaining cases, i.e., immigrants before first capture and all individuals not removed or died at last capture, we need to correct the observed residency time. In the absence of firm theoretical background, we follow Andrzejewski $(1963,1969)$ in basing this correction on the mean recapture time, $T r^{\prime}$ : Andrzejewski (1969) adds $T r^{\prime}$ days before the first capture and $\operatorname{Tr}^{\prime} / 2$ days after the last one; instead, we treat both situations symmetricallyy and add $T r^{\prime}$ days in each case.

Mean cohort $\operatorname{Tr}_{G}^{\prime}$ values are used when homogeneity of probability of capture 
is not rejected, and individual $\operatorname{Tr}_{i}^{\prime}$ values are used otherwise. These additional days of estimated presence are reported on table 6 by $x_{i j}=\ldots$. For the native young, this extends back to the mean cohort's birthdate, which for both $K-1$ and $K-2$ is anterior to series 1 of Table 6 .

The minimum number of individuals present, may now be estimated for series j, by:

(6) $m_{j j}^{\prime}=\sum_{i=1}^{N}\left(X_{i j}^{\prime} \geqslant-\right)$

where as before, $X^{\prime}$ is the reduced $X$ matrix having as columns the trapping series, and as $X_{i j}^{\prime}$ value, the maximum of $X_{i k}$ values in the original matrix, for the $k$ days of trapping series $j$. This means that an individual consdiered as present in at least one day of series $j$, is considered present on that series. The $m^{\prime}{ }_{j j}$ notation is used for consistency with later symbolism; $m_{j j}^{\prime}$ values are illustrated for each cohort during 1971 in Fig. 3.

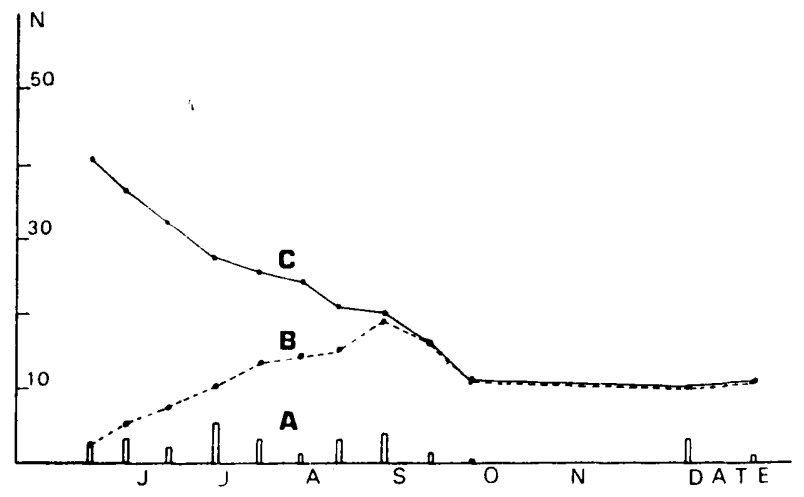

Fig. 12. Number of first captures per series (a), minimum number known to be present (classical C.C.) (b) and density estimation by the modified C.C. method (c) for cohoit $K 1-K 2$ during 1971.

The second step in our density estimation process, originates in the commonplace fact, that native young ones dying before their first capture, will never be cbserved. In order to estimate their numbers, we start with a survival table where the numbers of survivors are splitted according to the date of their first capture. Let us call $n_{j k}$, the number still present at series $j$, among the individuals first captured at series $k$ :

(7) $n_{j k}=\sum_{i=1}^{N}\left(X_{i j}^{\prime} \geqslant \Theta \mid X_{i k}^{\prime}=2\right)(k \leqslant j ; \mid$ means »conditional to $)$.

$n_{k}$ values are illustrated in Table $7 \mathrm{~A}$ for the combined $K-1$ and $K-2$ cohort. In this table, it is essential that immigrants be distinguished from native individuals; in Table 7A, immigrants are in parentheses.

Cumulating from left to right the columns of Table 7A, we obtain $m_{j k}$, the 
number still present at series $j$, among the individuals first captured at or before series $k$ (Table $7 \mathrm{~B}$ ):

(8) $m_{j k}=\sum_{h=1}^{k} n_{j h}$

with

(9) $m_{j j}=\sum_{i=1}^{N}\left(X_{i j}^{\prime} \geqslant \Theta\right)$, the minimum number present at series $j$.

The definition of $n_{j k}$ may be extended to represent the (unknown) number of individuals present before first capture:

let $n_{k-1, k}$ be the number of individuals present at series $k-1$, whose survivors will be first captured at series $k$. In order to estimate this number, we need an estimation of the survival rate between series $k-1$ and $k$. This estimation may be based onthe cohort's members already marked at series $k-1, m_{k-1}, k_{k-1}$. If the mortality rate may be assumed constant over the period $k-1$ to $k$, it may be estimated by:

(10) $\hat{\mu}_{k}=\ln \left(m_{k, k-1} / m_{k-1, k-1}\right) / t_{k}$

where $t_{k}$ is the number of days from series $k-1$ to series $k$, and $1 \mathrm{n}$ stands for natural logarithm. In the present study, due to paucity of data, we assume the mortality rate to be constant from the series when the first cohort's members are marked $(S f)$ to the series when the last cohort's members are marked $(S 1)$; a pooled estimation of the daily mortality rate is:

(11) $\hat{\mu .}=\sum_{k=S f}^{S 1} \ln \left(m_{k, k-1} / m_{k-1, k-1}\right) / \sum_{k=S f}^{S 1} t_{k}$

These mortality rates are presented in Table 2, per cohort and season. The survival rate between series $k-1$ and $k$ writes:

(12 $\hat{\Phi}_{k}=\exp \left(\hat{\mu} . t_{k}\right) \quad(\exp$ : exponential).

Assuming an equal survival rate for marked and unmarked cohort's members, (13) $i_{k-1, k}=\widehat{\Phi}_{k}-1 \cdot n_{k k}$

is the estimated number of individuals present at series $k-1$, whose survivors $k$. The process may be repeated to obtain $\hat{n}_{k-2, k}$, ... back to series $S f$.

Our final density estimation thus writes:

(14) $\hat{n}_{\cdot j}=m^{\prime}{ }_{j j}+\sum_{k=j+1}^{S 1} \hat{n}_{j k}$

The first term is the number of individuals already present at series $j$ (on the basis of estimated residency time), the second term estimates the number of natize young ones present before their first capture. These values are reported in Table 8 and Fig. 12 for cohort $K-1-K-2$. 


\section{Fric LE BOULENGE i Paule Y. LE MOULENGE-NGUYEN}

\section{BADANIA EKOLOGICZNE POPULACJI PIŻMAKA}

\section{Streszczenie}

Od lutego 1970 roku do stycznia 1972 roku badano dynamikę populacji piżmaka. Badania prowadzono na izolowanym $7,5 \mathrm{~km}$ odcinku wzdłuż rzeki Houille w południowej Belgii (Ryc. 1). Stosowano metodę CMR, a następnie całkowity wyłów wszystkich zwierząt na badanym terenie (Tabela 1, Ryc. 2). Ogółem, w ciągu 295 dni odłowu złapano 843 piżmaki (Ryc. 3). Stała kontrola powierzchni badawczych pozwoliła na prześledzenie procesu rozpraszania się i migracji piżmaka.

Metoda oceny zagęszczenia przy pomocy kalendarza złowień została nieco zmodyfikowana, w celu możliwości odróżnienia osobników osiadłych od imigrantów. W zmodyfikowanej metodzie kalendarza złowień nie zakładano, że łowność jest jednakowa $w$ odniesieniu do wszystkich osobników w populacji, ale przyjmowano że tempo ubywania znakowanych i nieznakowanych osobników osiadłych jest jednakowe (Ryc. 4, 5).

Roczna dynamika populacji cechowała się następującym wzorcem: (1) Zimowe zagęszczenie jest stałe w poszczególnych latach i wynosi okolo 3 osobników/km. (2) Obniżenie się występowania o około $50 \%$ na wiosnę, jest spowodowane zarówno emigracją (typ ,n’asyconego rozproszenia”) jak i śmiertelnością. Kilka danych opartych na behawiorze przestrzennym i socjalnym oraz na lowności wskazuje, że to obniżenie liczebności jest mechanizmem regulującym rozrodczość (Ryc. 6). (3) Dzięki rozrodowi zagęszczanie osiąga w lipcu szczyt 11 osobników na $1 \mathrm{~km}$., następnie jesienny spadek aż do zimowego poziomu jest wywołany śmiertelnością młodych, niejednakową w kolejnych kohortach (Tabela 2). Najważniejszą przyczyną tego zróżnicowania wydaje się być konkurencja i agresywność dorosłych samic (Tabela 3, Ryc. 8). (4) W jesieni wystçpują pewne przetasowania wśród człon'ków populacji. (5) Roczna śmiertelność wynosi $80-90 \%$ dorosłych, oraz $80-90 \%$ młodych ginie przed swą pierwszą zimą. 